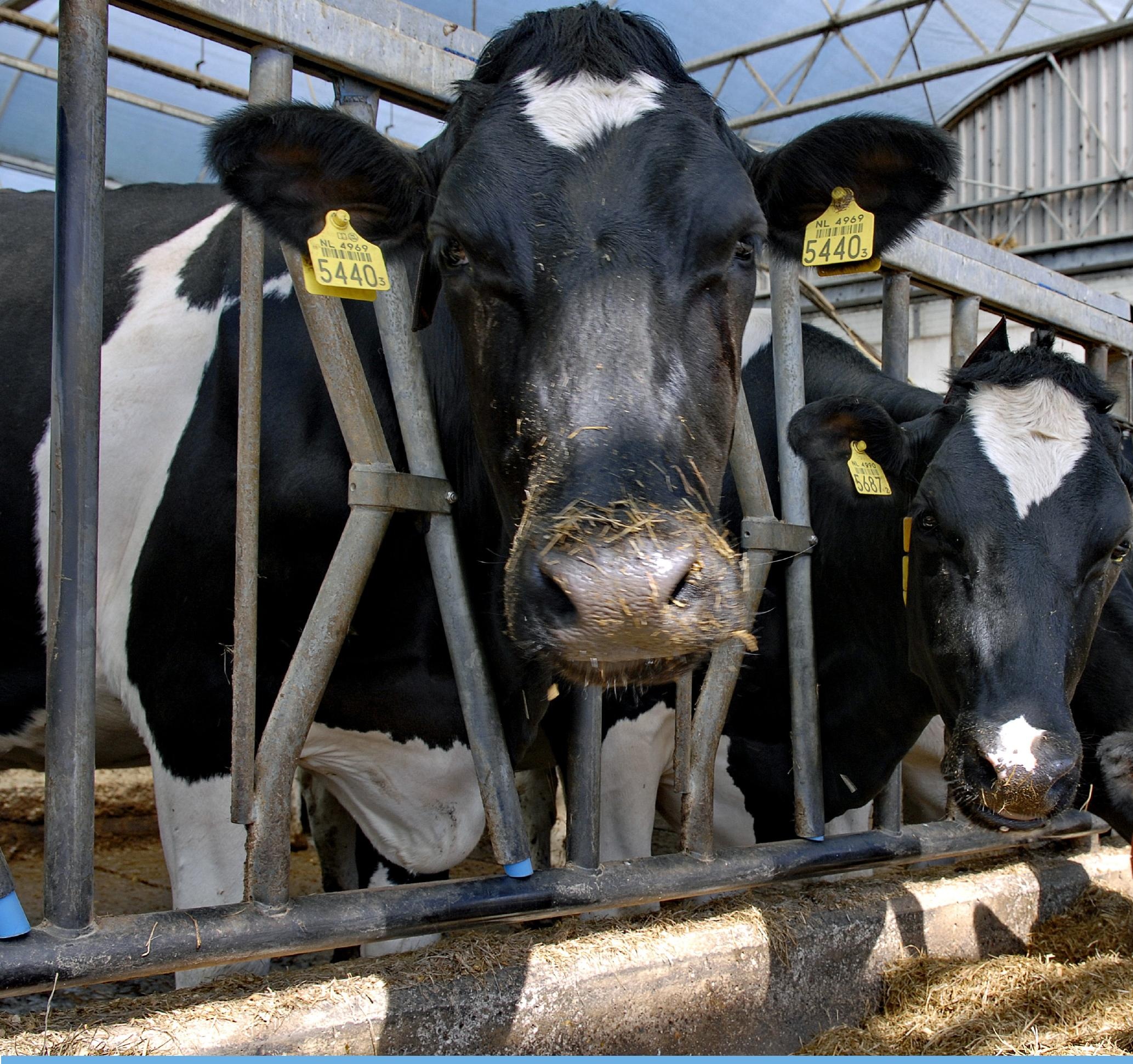

Phosphorus in transition cows

A dairy cow trial on phosphorus metabolism in the transition period 



\section{Phosphorus in transition cows}

A dairy cow trial on phosphorus metabolism in the transition period

R.M.A. Goselink ${ }^{1}$, A. Bannink ${ }^{1}$, J. Dijkstra²

1 Wageningen Livestock Research

2 Wageningen University

This research was conducted by Wageningen Livestock Research, within the framework of the public private partnership "Feed4Foodure" and partially funded by the Ministry of Agriculture, Nature and Food Quality

Wageningen Livestock Research

Wageningen, December 2019

Report 1221 
Goselink, R.M.A., A. Bannink, J. Dijkstra, 2019. Phosphorus in transition cows; a dairy cow trial on phosphorus metabolism in the transition period. Wageningen Livestock Research, Report 1221.

Samenvatting NL In deze studie is het effect van verschillende fosfor $(P)$ niveaus in melkveerantsoenen onderzocht gedurende de transitieperiode, voor wat betreft de productieprestaties en diergezondheid. Het overvoeren van $\mathrm{P}$ in de droogstand (185\% vs. $100 \%$ van de behoeftenorm) had geen invloed op de voeropname of melkproductie postpartum, maar verlaagde plasma $\mathrm{P}$ en $\mathrm{Ca}$ concentraties en verhoogde juist het risico op hypocalcemie. Een reductie van de hoeveelheid $\mathrm{P}$ in lactatierantsoenen ( $70 \%$ vs. $100 \%$ ) verlaagde de plasma P concentratie, verhoogde de plasma Ca concentratie en de $\mathrm{P}$ mobilisatie en verlaagde de excretie van $\mathrm{P}$ met de mest. Desondanks zijn er geen negatieve gevolgen geconstateerd van een lactatierantsoen met een $\mathrm{P}$ gehalte onder de berekende behoefte, voor wat betreft de productieprestaties of de diergezondheid in de eerste acht weken na kalven.

Summary UK The present study evaluates the effect of different dietary phosphorus (P) levels in dairy cattle during the transition period, focussing on animal performance and animal health. Overfeeding $P$ in the dry period ( $185 \%$ vs. $100 \%$ of requirements) did not affect feed intake or milk yield postpartum, but decreased plasma $\mathrm{P}$ and $\mathrm{Ca}$ concentrations and increased the risk for periparturient hypocalcemia. A reduction of the dietary $\mathrm{P}$ content in lactation diets (70\% vs. $100 \%)$ reduced the average plasma $\mathrm{P}$ concentration, increased plasma Ca concentration and $\mathrm{P}$ mobilisation and reduced faecal excretion of P. However, no negative effects on cow performance or animal health were found for diets with a $\mathrm{P}$ content below calculated requirements in the first eight weeks postpartum.

This report can be downloaded for free at https://doi.org/10.18174/510336 or at www.wur.nl/livestock-research (under Wageningen Livestock Research publications).

(C) 2019 Wageningen Livestock Research

P.O. Box 338, 6700 AH Wageningen, The Netherlands, T +31 (0)317 483953 ,

E info.livestockresearch@wur.nl, www.wur.nl/livestock-research. Wageningen Livestock Research is part of Wageningen University \& Research.

All rights reserved. No part of this publication may be reproduced and/or made public, whether by print, photocopy, microfilm or any other means, without the prior permission of the publisher or author.

Wageningen Livestock Research is NEN-EN-ISO 9001:2015 certified.

All our research commissions are in line with the Terms and Conditions of the Animal Sciences Group. These are filed with the District Court of Zwolle. 


\section{Table of contents}

$\begin{array}{ll}\text { Foreword } & 5\end{array}$

$\begin{array}{ll}\text { Summary } & 7\end{array}$

1

$\begin{array}{ll}\text { Introduction } & 9\end{array}$

$\begin{array}{lll}1.1 & \text { Background } & 9\end{array}$

1.2 Research objectives $\quad 9$

2

$\begin{array}{lr}\text { Materials and Methods } & 10\end{array}$

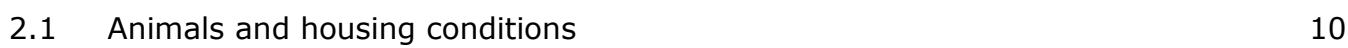

2.2 Experimental design $\quad 10$

2.2.1 Experimental groups 10

2.2.2 Ration composition 11

2.2.3 Data collection $\quad 11$

2.2.4 Calculations and statistical analysis $\quad 12$

3

$\begin{array}{ll}\text { Results and Discussion } & 13\end{array}$

3.1 General 13

3.2 Rations 13

$\begin{array}{lll}3.3 & \text { Precalving performance } & 16\end{array}$

3.4 Postcalving performance 16

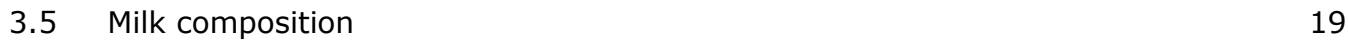

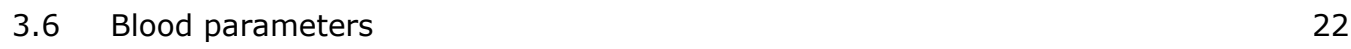

$\begin{array}{lll}3.7 & \text { Health } & 25\end{array}$

$\begin{array}{lll}3.8 & \text { Feed digestibility and P excretion } & 27\end{array}$

4

$\begin{array}{ll}\text { Conclusions } & 30\end{array}$

$\begin{array}{ll}\text { References } & 31\end{array}$

Appendix 1 Chemical analysis and feeding value of dietary ingredients 32

$\begin{array}{lll}\text { Appendix } 2 & \text { Additional figures } & 35\end{array}$ 



\section{Foreword}

This research project was conducted within the research programme "Feed4Foodure": a public-private partnership between the Dutch Ministry of Economic Affairs and a consortium of various organizations within the animal feed industry and the animal production chain. Feed4Foodure aims to contribute to sustainable and healthy livestock farming in the Netherlands, simultaneously strengthening our competitive position on the global market.

The research programme comprises three main research lines: socially responsible livestock farming; nutrition, gut health and immunity; and "more-with-less" by efficient nutrient use. The aim of this third research line, "More with Less", is to reduce the footprint of the Dutch livestock sector in the field of phosphate, nitrate, copper, zinc, ammonia and greenhouse gases. New nutritional models and measurement techniques will be developed to improve efficient use of nutrients in livestock farming.

The present study entitled "Phosphorus in transition; a dairy cow trial on phosphorus metabolism in the transition period" was performed within research line "More with Less", theme 4: "Reduction of phosphorus losses". Main aim of this subproject is to gain insight in the dynamics and regulation of phosphorus absorption, mobilisation and utilization in farm animals to update the current phosphorus requirements for farm animals, thereby improving phosphorus efficiency.

For dairy cattle, much work has been done to understand phosphorus digestion, absorption and metabolism, but the regulation of phosphorus homeostasis, especially during the transition period, is not fully understood. In the present study we investigated the effect of different levels of phosphorus in dry cow and lactation rations on dairy cow health, performance and phosphorus efficiency in the transition period.

Roselinde Goselink

André Bannink

Jan Dijkstra 


\section{Summary}

The regulation of phosphorus $(P)$ in dairy cattle is still not fully understood, especially during the transition period with low $\mathrm{P}$ requirements in the dry period and high $\mathrm{P}$ requirements directly after calving due to the output of $P$ with milk. In the present trial the effect of varying $P$ intake in the dry period (starting 6 weeks before calving; $185 \%$ and $100 \%$ of $P$ requirement) as well as the first 8 weeks of lactation ( $100 \%$ vs. $70 \%$ of $\mathrm{P}$ requirement) was evaluated in a randomised block design with 60 multiparous dairy cows.

Overfeeding $\mathrm{P}$ in the dry period ( $3.6 \mathrm{~g} \mathrm{P} / \mathrm{kg} \mathrm{DM}$ ) did not affect feed intake, milk yield or milk composition after calving compared to a diet fed at requirements $(2.2 \mathrm{~g} \mathrm{P} / \mathrm{kg} \mathrm{DM})$. Monitoring $\mathrm{P}$ excretion with faeces showed that the additional $P$ ingested by overfeeding was excreted and did not accumulate in the body. On the contrary, overfeeding $\mathrm{P}$ in the dry period negatively affected plasma calcium concentration postpartum, and increased the risk for periparturient hypocalcemia.

A reduction of the dietary $P$ content in lactation diets below the calculated requirements $(2.9 \mathrm{~g} \mathrm{P} / \mathrm{kg}$ DM) reduced average plasma $P$ concentration and increased plasma Ca concentration in the first 8 weeks postpartum compared to a diet at requirements $(3.8 \mathrm{~g} \mathrm{P} / \mathrm{kg} \mathrm{DM})$. Cows on both diets mobilised $\mathrm{P}$ from body reserves postpartum; mobilisation was highest for the low $\mathrm{P}$ diet $(14 \mathrm{~g} / \mathrm{d}$ compared to 9 $\mathrm{g} / \mathrm{d}$ ) and faecal excretion was reduced ( $34 \mathrm{~g} / \mathrm{d}$ compared to $47 \mathrm{~g} / \mathrm{d}$ ). Feeding around $70 \%$ of calculated $P$ requirements in the first 8 weeks postpartum with a diet containing $2.9 \mathrm{~g} \mathrm{P} / \mathrm{kg}$ did however not affect feed intake, feed digestibility, milk yield, milk composition or animal health. The maximal duration of this period of $\mathrm{P}$ mobilisation requires further research. 


\section{Introduction}

\section{$1.1 \quad$ Background}

In dairy cattle physiology, the regulation of phosphorus $(P)$ is still not fully understood, especially during the transition period. The Dutch requirements as defined by the Product Board Animal Feed are internationally the lowest for high yielding dairy cattle. Most Dutch dairy rations contain sufficient $P$ to match the $P$ requirements for the largest part of the lactation cycle. During the dry period $P$ requirements are low, relative to the $\mathrm{P}$ content of the rations. Directly after calving, the risk for a $\mathrm{P}$ deficiency is largest, as the feed intake is still low while the milk P content (and the animal's P requirement) is high. Experience of farmers and veterinarians in practice suggests that this $P$ deficiency may play a role in health disorders immediately after calving. The scientific base for this relationship is however still insufficient.

Looking at the required reduction in the $\mathrm{P}$ excretion of the dairy sector, knowledge of $\mathrm{P}$ metabolism in dairy cattle gains importance to further improve $\mathrm{P}$ efficiency without harming digestion, production or animal health.

\subsection{Research objectives}

The present trial investigates the effect of varying $\mathrm{P}$ content in dairy cow rations during the transition period to answer the following questions:

- What is the effect of a high $\mathbf{P}$ intake in the dry period ( $185 \%$ relative to requirement) on animal health, feed intake, milk yield and milk composition of cows after calving?

- What is the effect of a low P intake during the first 8 weeks of lactation (70\% relative to requirement) on animal health, feed intake, milk yield and milk composition of cows after calving?

- What is the effect of total $P$ intake in the dry period and the lactation on the digestibility of the rations?

- What is the calculated mobilisation of $\mathbf{P}$ from body reserves at different levels of $P$ intake in the dry period and the lactation? 


\section{Materials and Methods}

\subsection{Animals and housing conditions}

The trial was performed at Dairy Campus, Boksumerdyk 11, 9084 AA Leeuwarden between 16 January and 4 September 2017. All experimental protocols and interventions were approved by the Ethics Committee on Animal Experiments of the Animal Sciences Group of Wageningen University and Research Centre, the Netherlands.

A total number of 60 pregnant Holstein Friesian dairy cows were selected from the 500-head herd, based on their parity (at least two previous calvings) and expected calving date. All cows entered the trial 39-45 days before expected calving date and were monitored until 8 weeks after calving. All cows are housed in two groups in the nutrition barn: a dry-cow group, and a postpartum lactation group. Close to calving, animals were moved to the transition barn; after calving the animals returned to the nutrition barn as soon as permitted by their physical condition.

All animals were fed a roughage-based ration ad libitum, fed in feeding bins of the Roughage Intake Control system (RIC; Hokofarm Group, Marknesse, the Netherlands) to measure individual feed intake. Freshly mixed rations were provided automatically four times during the day by an automatic feeding system (Trioliet, Oldenzaal, the Netherlands). Additionally concentrates were fed individually by transponder-controlled concentrate feeders. Drinking water was provided ad libitum. All animals were milked twice daily with an inter milking interval of 11 to 13 hours.

\subsection{Experimental design}

\subsubsection{Experimental groups}

Before entering the trial, animals were grouped in 15 blocks of 4 animals based on similarity in expected calving dates, parity and milk production in the previous lactation. Individual animals from each block were randomly assigned to one of four treatment groups: D100/L100, D185/L100, D100/L70 and D185/L70.

\begin{tabular}{|c|c|c|c|c|c|c|}
\hline \multicolumn{2}{|c|}{ GROUP } & \multicolumn{2}{|c|}{ Dry period (6 weeks) } & \multirow{5}{*}{$\frac{\text { ס }}{\text { 至 }}$} & \multicolumn{2}{|c|}{ Lactation ( 8 weeks) } \\
\hline D100 & L70 & Dry100 & 30 соияс & & $\begin{array}{c}\text { Lac70 } \\
2.6 \mathrm{~g} \mathrm{P} / \mathrm{kg} \mathrm{DM}\end{array}$ & 15 cows \\
\hline D100 & L100 & $2.0 \mathrm{~g} \mathrm{P} / \mathrm{kg} \mathrm{DM}$ & 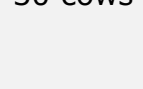 & & 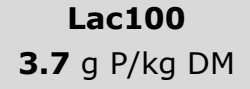 & 15 cows \\
\hline D185 & L70 & Dry185 & 30 cows & & $\begin{array}{c}\text { Lac70 } \\
2.6 \mathrm{~g} \mathrm{P} / \mathrm{kg} \mathrm{DM}\end{array}$ & 15 cows \\
\hline D185 & L100 & $3.7 \mathrm{~g} \mathrm{P} / \mathrm{kg} \mathrm{DM}$ & 30 cows & & $\begin{array}{c}\text { Lac100 } \\
\text { 3.7 g P/kg DM }\end{array}$ & 15 cows \\
\hline
\end{tabular}

Each treatment group received a different combination of rations varying in $\mathrm{P}$ content relative to the calculated $\mathrm{P}$ requirements, according to the calculations of the Dutch Product Board Animal Feed (COMV, 2005). Calculations were based on the expected dry matter intake, requirements for gestation (in the dry period), the expected milk yield (in early lactation) and an average net absorption of $75 \%$. 
This resulted in the following treatment groups:

- $\mathbf{D 1 0 0 / L 1 0 0}(n=15)$ : both the dry cow ration and the lactation ration aimed at a $P$ intake equal to the $P$ requirements $(100 \%)$.

- $\mathbf{D 1 8 5 / L 1 0 0}(n=15)$ : the dry cow ration contained a higher level of $P$ relative to the $P$ requirements $(185 \%)$, while the lactation ration aimed at a $P$ intake equal to the $P$ requirements $(100 \%)$.

- D100/L70 $(n=15)$ : the dry cow ration aimed at a $P$ intake equal to the $P$ requirements $(100 \%)$, while the $P$ content of the lactation ration was below the $P$ requirements $(70 \%)$.

- D185/L70 $(n=15)$ : the dry cow ration contained a higher level of $P$ relative to the $P$ requirements $(185 \%)$, while the $\mathrm{P}$ content of the lactation ration was below the $\mathrm{P}$ requirements $(70 \%)$.

\subsubsection{Ration composition}

The basal dry cow ration was composed of maize silage, grass silage, wheat straw and a mineral and vitamin premix. Additionally, all cows received $1 \mathrm{~kg}$ of compound concentrate with $\mathrm{TiO}_{2}$ added as an indigestible marker fed in individual concentrate dispensers (10 g Ti per $\mathrm{kg}$ ). During lactation, the basal ration was composed of maize silage, grass silage, soy bean meal and a mineral and vitamin premix. During lactation, all cows received $2 \mathrm{~kg}$ of compound concentrate with $\mathrm{TiO}_{2}$ as an indigestible marker ( $5 \mathrm{~g}$ Ti per $\mathrm{kg}$ ) and a second compound concentrate starting at $1 \mathrm{~kg}$ the day after calving, gradually increasing up to $7.3 \mathrm{~kg}$ at day 21 postpartum.

The level of $\mathrm{P}$ in the rations was varied by adding inorganic $\mathrm{P}\left(\mathrm{Na}_{2} \mathrm{PO}_{4}\right)$ to the low $\mathrm{P}$ premix and the low $\mathrm{P}$ lactation concentrate, in exchange for $\mathrm{NaCO}_{3}$ in the high $\mathrm{P}$ premix and the high $\mathrm{P}$ lactation concentrate, to compensate for a potential difference in sodium intake. This resulted in two dry cow diets (Dry100 and Dry 185) and two lactation diets (Lac70 and Lac100).

Table 2.1 Average ration composition.

\begin{tabular}{|c|c|c|c|c|}
\hline Ingredient & Dry 100 & Dry 185 & Lac70 & Lac100 \\
\hline \multicolumn{5}{|c|}{ Ingredients of feed mixture in $\%$ of DM } \\
\hline Maize silage & 39.7 & 39.3 & 69.0 & 70.0 \\
\hline Wheat straw & 32.0 & 31.5 & - & - \\
\hline Soy bean meal & - & - & 6.4 & 5.4 \\
\hline Premix low $\mathrm{P}$ & 4.5 & - & 3.3 & - \\
\hline \multicolumn{5}{|c|}{ Compound concentrates in kg/cow per day } \\
\hline Marker dry period & 1.0 & 1.0 & - & - \\
\hline Marker lactation & - & - & 2.0 & 2.0 \\
\hline Lactation concentrate low $\mathrm{P}$ & - & - & $7.3 *$ & - \\
\hline
\end{tabular}

*Lactation concentrate was gradually increased from $1.0 \mathrm{~kg} / \mathrm{d}$ at d1 postcalving until $7.3 \mathrm{~kg} / \mathrm{d}$ at d21 postcalving.

\subsubsection{Data collection}

General performance data

Total intake of the roughage diet was registered automatically by the RIC feeding bins (kg/cow/day).

Milk yield was registered at each milking and combined to a daily milk yield $(\mathrm{kg} / \mathrm{d})$. Live weight was registered once a week during the dry period; after calving, all cows were weighed at each milking after leaving the milking parlour. Body condition was scored weekly on a 1 to 5 scale with 0.25 increments.

\section{Feed samples}

For the determination of dry matter content, maize and grass silage were sampled daily while wheat straw, soy bean meal and the premixes fed in the roughage diet were sampled weekly. Dry matter content was determined by calculating the weight difference before and after oven drying at $104^{\circ} \mathrm{C}$ during 36 hours. Every day the relative contribution of each of the ration components to the mixture 
was registered ( $\mathrm{kg}$ product of each component mixed) and with this information, average DM content of the mixture was calculated. Dry matter intake per individual cow was calculated by multiplying dry matter content of the mixture with daily intake of fresh product.

Next to the dry matter determination, all ingredients and compound concentrates were sampled once per week and frozen for chemical analysis.

\section{Milk samples}

Milk was sampled weekly for the determination of milk composition. During four consecutive milkings, milk was sampled and pooled in two tubes: one for the two morning milkings, and one for the two evening milkings. Samples were analysed fresh by mid-infrared spectrometry (Qlip, Zutphen, The Netherlands) for fat, protein, lactose and urea concentration, and somatic cell count.

Two separate milkings (one morning and one evening) were sampled and stored frozen $\left(-20^{\circ} \mathrm{C}\right)$. These two milk samples were pooled and analyzed by ICP-MS for P content (Qlip, Zutphen, The Netherlands).

\section{Blood samples}

Blood was sampled according to a standardized schedule relative to the (expected) day of calving. Before calving, three samples were taken on Thursdays in week $-4,-2$ and -1 relative to the expected calving date. If the actual calving date was later than expected, additional blood samples were taken weekly until calving. Immediately after calving, the fourth sample was taken ( $\mathrm{d} 0)$. After that, 8 samples were taken during lactation: on d1, d2, d3, d7, d14, d21, d28 and d56. Samples planned for weekend days were taken on the closest weekday (Saturday to Friday; Sunday to Monday).

At each sampling time, blood was collected in serum separator tubes and samples were left 30 min at room temperature to coagulate. Tubes were then centrifuged for 15 min at 3,000 RPM and plasma was transferred to plasma tubes and stored at $-20^{\circ} \mathrm{C}$. All samples were analysed for plasma $\mathrm{P}$ concentration (with ammonium molybdate) and Ca concentration (with Arsenazo III) using an automatic analyser (ABX Pentra 400, Horiba, Europe $\mathrm{GmbH}$, Langenhagen, Germany). Non-esterified fatty acids (NEFA) and $\beta$-hydroxybutyric acid (BHB) concentration were also determined by an automatic analyser (Cobas Mira Plus System from Roche Diagnostica Ltd, Basel, Switzerland) using commercial test kits (NEFA: HR(2) R1+R2 Set, WAKO Chemicals GmbH, Neuss, Germany; BHB: RANBUT, RB 1008, Randox Laboratories $\mathrm{GmbH}$, Wülfrath, Germany). Analysis of bone resorption marker CTX, parathyroid hormone PTH, and 25-hydroxyvitamin $\mathrm{D}_{3}$ were conducted by means of commercially available ELISA kits (CTX: Serum CrossLaps ELISA, Immundiagnostic Systems (ids) GmbH, Frankfurt am Main, Germany; PTH: Bovine Intact PTH ELISA Kit; Immuntopics Inc., San Clement, $C A$; 25-hydroxyvitamin $\mathrm{D}_{3}$ : 25(OH)-Vitamin D direct day ELISA, Immundiagnostik AG, Bensheim, Germany).

\section{Faecal samples}

Faeces was sampled at biweekly intervals, except for the week of calving, in week -4, -2, 2, 4, 6 and 8 relative to the (expected) calving date. In each sampling week, faeces was sampled three days in a row at different time intervals to create a representative sample of average excretion. Timing was around 8.00 and $14.00 \mathrm{~h}$ on day 1 , around 10.00 and $16.00 \mathrm{~h}$ on day 2 and around 12.00 and $18.00 \mathrm{~h}$ on day 3, after which these samples (pooled per cow) were stored frozen at $-20^{\circ} \mathrm{C}$.

Recovery of $\mathrm{Ti}$ in faecal samples was used to estimate total faecal production (and $\mathrm{P}$ excretion) per day.

\subsubsection{Calculations and statistical analysis}

Daily feed intake, milk yield, live weight and calculated energy balance were averaged per cow per week relative to calving.

Data was analysed using the software package Genstat 18th edition (2015) by repeated measures ANOVA for the prepartum period and the postpartum period separately. The dry cow diet (Dry 100 or Dry185), lactation diet (Lac70 or Lac100) and their interactions were included as fixed factors, and subject within block as random factors. All factors were kept in the model and significant factor effects were determined by the significance value set at $\mathrm{P}<0.05$ and the tendency level at $\mathrm{P}<0.10$.

A chi-square analysis was used to test the difference in the incidence of diseases between dietary treatments. 


\section{Results and Discussion}

\subsection{General}

One cow (1206) in group D185/L70 received the high P concentrate during lactation with the Lac70 basal diet, due to an administrative mistake. This did not affect total $\mathrm{P}$ coverage much, and calculated $\mathrm{P}$ balance was negative during the full 8 weeks of lactation (increasing from 75 to 90\%). For correct analysis of dietary effects, performance and blood results of this cow in week 1 to 8 postpartum was excluded from all statistical analyses.

One cow (7048) in group D100/L70 suffered from a teat injury in week 7 of lactation. Her results were excluded for week 7 and 8 . All other cows completed the trial.

\subsection{Rations}

During the experimental period of 8 months, grass and maize silage composition varied due to natural variation in harvesting conditions and conservation which affected the dietary $P$ concentration of the roughage mixture.

Next to the roughage mixture which was fed ad libitum, compound concentrates were supplied individually at restricted levels: $1 \mathrm{~kg} / \mathrm{d}$ marker concentrate precalving, $2 \mathrm{~kg} / \mathrm{d}$ marker concentrate postcalving, and a lactation concentrate increasing from $1 \mathrm{~kg} / \mathrm{d}$ to $7.3 \mathrm{~kg} / \mathrm{d}$ in the first 21 days after calving.

The average $P$ content of the dietary ingredients throughout the study is shown in Table 3.1. Total chemical analysis of the dietary ingredients is reported in Appendix 1.

Table 3.1 Average $P$ content of dietary ingredients and additional compound concentrates.

\begin{tabular}{|c|c|}
\hline Ingredient & P content \\
\hline \multicolumn{2}{|c|}{ Roughage mixture ingredients ( $\mathrm{g} / \mathrm{kg} \mathrm{DM})$} \\
\hline Maize silage & 2.3 \\
\hline Wheat straw & 0.7 \\
\hline Soy bean meal & 6.8 \\
\hline Premix low $\mathrm{P}$ & 2.2 \\
\hline \multicolumn{2}{|l|}{ Compound concentrates $(\mathrm{g} / \mathrm{kg}$ ) } \\
\hline Marker dry period & 2.9 \\
\hline Marker lactation & 2.9 \\
\hline Lactation concentrate low P & 2.3 \\
\hline
\end{tabular}

Chemical analysis of the ration ingredients and actual intake of the roughage mixture combined with the compound concentrates resulted in an average chemical composition and feeding value of the total diets as shown in Table 3.2. 
Table 3.2 Average chemical composition and feeding value of total diet (roughage mixtures and compound concentrates).

\begin{tabular}{|c|c|c|c|c|}
\hline Total diet & Dry 100 & Dry 185 & Lac70 & Lac100 \\
\hline \multicolumn{5}{|c|}{ Chemical composition ( $g$ per $\mathrm{kg}$ of DM) } \\
\hline OM & 926 & 924 & 930 & 931 \\
\hline $\mathrm{CP}$ & 105 & 106 & 150 & 149 \\
\hline Crude fibre & 269 & 268 & 183 & 183 \\
\hline ADF & 301 & 298 & 214 & 214 \\
\hline ADL & 35 & 35 & 25 & 23 \\
\hline Crude fat & 27 & 27 & 32 & 33 \\
\hline Starch & 136 & 136 & 206 & 206 \\
\hline Sugars & 21 & 21 & 41 & 39 \\
\hline $\mathrm{S}$ & 1.9 & 1.9 & 2.2 & 2.2 \\
\hline $\mathrm{Cl}$ & 3.5 & 3.6 & 3.7 & 3.3 \\
\hline DCAD (mEq/kg DM) & 299 & 307 & 248 & 263 \\
\hline \multicolumn{5}{|c|}{ Feeding value ( $g$ per $k g$ of DM) } \\
\hline Digestible OM & 631 & 629 & 733 & 730 \\
\hline Fermentable OM & 505 & 503 & 557 & 556 \\
\hline $\mathrm{NE}_{\mathrm{L}}(\mathrm{MJ} / \mathrm{kg} \mathrm{DM})$ & 5.59 & 5.58 & 6.77 & 6.76 \\
\hline $\mathrm{NE}_{\mathrm{L}}(\mathrm{VEM} / \mathrm{kg} \mathrm{DM})$ & 810 & 808 & 981 & 979 \\
\hline DVE* 1991 & 57 & 57 & 93 & 92 \\
\hline
\end{tabular}

*DVE (Darm Verteerbaar Eiwit): intestinal digestible protein according to CVB.

\#OEB (Onbestendig Eiwit Balans): rumen digestible protein balance according to CVB.

As shown in Table 3.2, the dry cow ration at requirement level (Dry100) contained on average 2.2 $\mathrm{g} / \mathrm{kg}$ DM (planned: $2.0 \mathrm{~g} / \mathrm{kg} \mathrm{DM}$ ), while the high P ration (Dry 185 ) contained $3.6 \mathrm{~g} / \mathrm{kg} \mathrm{DM}$ (as planned). The lactation ration at requirement level (Lac100) contained $3.8 \mathrm{~g} / \mathrm{kg}$ DM (planned: 3.7 $\mathrm{g} / \mathrm{kg} \mathrm{DM}$ ) and the ration below P requirement (Lac70) had on average $2.9 \mathrm{~g} / \mathrm{kg}$ DM (planned: $2.6 \mathrm{~g} / \mathrm{kg}$ DM).

The average $\mathrm{P}$ intake per $\mathrm{kg}$ of DM for each individual cow during the trial is displayed in Figure 3.1A, together with the individual $P$ intake relative to the calculated requirements in Figure 3.1B. 


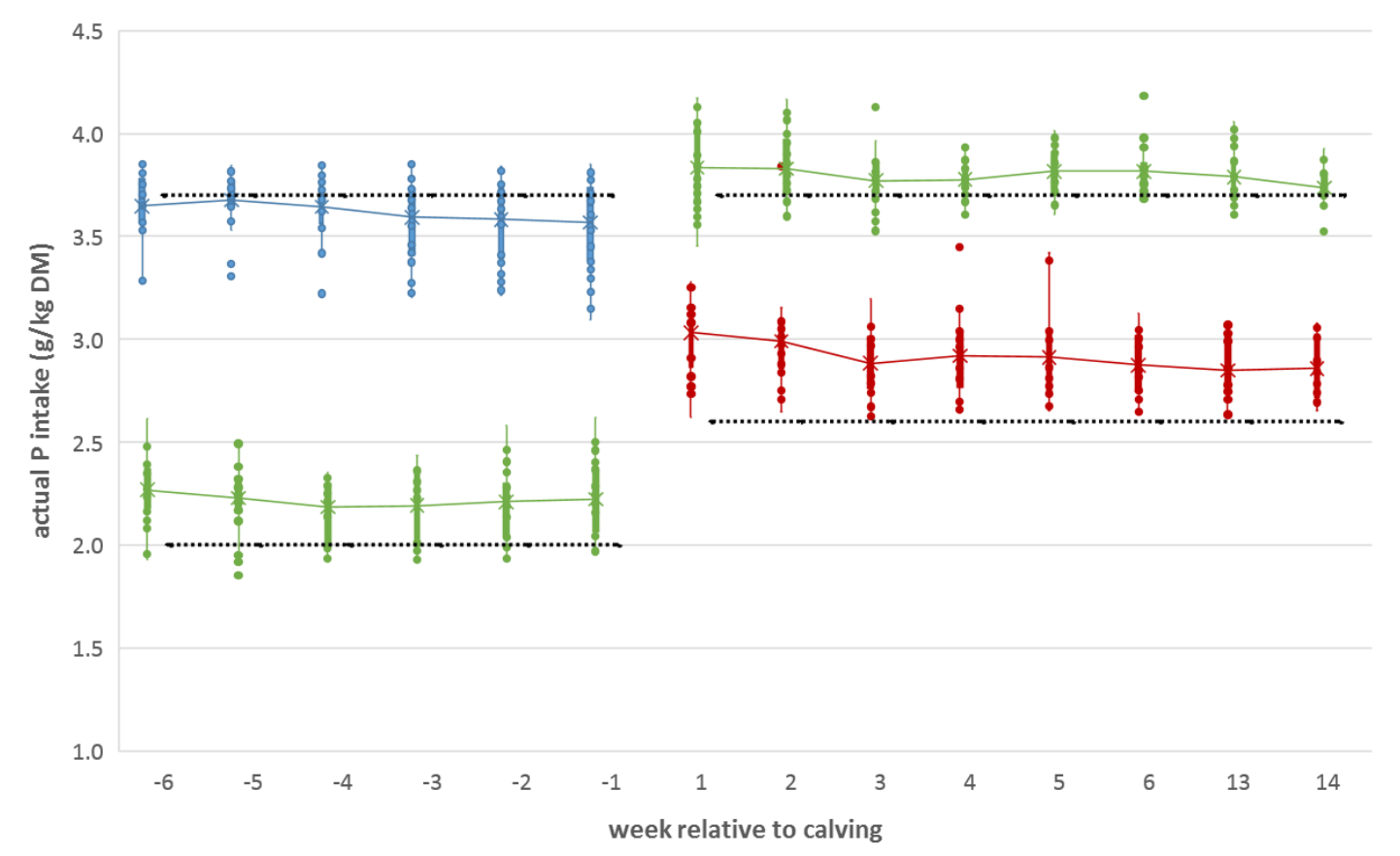

A

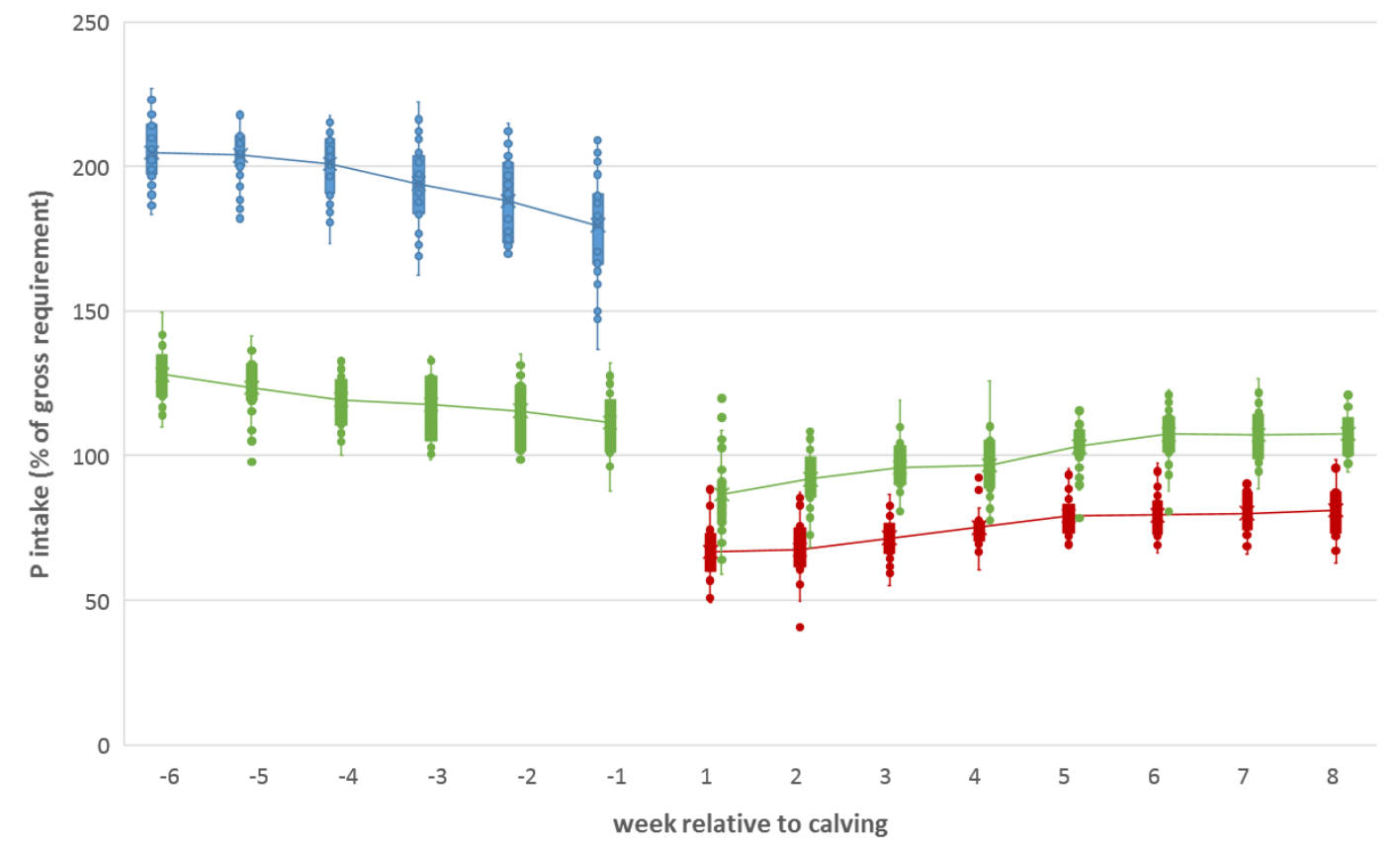

B

Blue cows on dry cow ration with P-level above calculated requirement (Dry185)

Green cows on dry cow and lactation ration with P-level at calculated requirement (Dry100 and Lac100)

Red cows on lactation ration with P-level below calculated requirement (Lac70)

Black dotted lines - intended dietary P-levels per ration

Figure 3.1 Average actual $P$ intake per cow per week, expressed as $\mathrm{g} / \mathrm{kg} D M(A)$ and as a \% of calculated gross $P$ requirement $(B)$. Each dot is an individual cow's week average.

In Figure 3.1B total average $\mathrm{P}$ intake per cow per week is expressed as a percentage of calculated gross $\mathrm{P}$ requirement (COMV, 2005). The difference in treatment groups on the calculated $\mathrm{P}$ coverage is clearly present, even though dietary intake of $P$ in $\mathrm{g} / \mathrm{kg}$ DM was higher than planned as displayed in Figure 3.1A.

On average cows on Dry 185 received $197 \%$ of gross $\mathrm{P}$ requirement and Dry 100 cows $119 \%$. For lactating animals, $\mathrm{P}$ intake was below calculated requirements for all cows on Lac70 diet, receiving on average $74 \%$ of gross $\mathrm{P}$ requirement; for cows on Lac100 diet, $\mathrm{P}$ intake was below calculated 
requirements in the first 4 weeks (on average $91 \%$ coverage) and turned positive in week 5 to 8 (on average $105 \%$ coverage).

\subsection{Precalving performance}

Precalving, a dietary P content of 3.6 vs. $2.2 \mathrm{~g} / \mathrm{kg}$ DM did not seem to affect dry matter intake or the development of body weight (Table 3.3). In the study of Puggaard et al. (2014), feed intake was not different between dry cows fed a diet with 1.7, 2.1 or $2.5 \mathrm{~g} \mathrm{P} / \mathrm{kg}$ DM. Valk and Šebek (1999) showed a $0.9 \mathrm{~kg}$ decrease in feed intake of dry cows fed a dry cow ration with $1.6 \mathrm{~g} \mathrm{P} / \mathrm{kg} \mathrm{DM}$ compared to cows fed $2.6 \mathrm{~g} \mathrm{P} / \mathrm{kg} \mathrm{DM}$. This level of $\mathrm{P}$, at $67 \%$ of calculated requirements, may affect diet digestibility; in the present study however, the lowest dietary P level was still well above $1.6 \mathrm{~g} \mathrm{P} / \mathrm{kg}$ DM and a difference in feed intake or body weight development is not expected.

Table 3.3 Performance precalving.

\begin{tabular}{|c|c|c|c|c|c|c|c|c|c|c|}
\hline & \multicolumn{6}{|c|}{ Week relative to calving } & \multirow[t]{2}{*}{ SED } & \multicolumn{3}{|c|}{ P-value } \\
\hline & -6 & -5 & -4 & -3 & -2 & -1 & & Dry & Week & Dry $\times W$ \\
\hline \multicolumn{11}{|c|}{ DMI (kg/d) } \\
\hline Dry185 & 14.2 & 14.2 & 14.8 & 14.3 & 13.5 & 12.1 & \multirow[t]{2}{*}{0.55} & \multirow[t]{2}{*}{0.778} & \multirow[t]{2}{*}{$<0.001$} & \multirow[t]{2}{*}{0.611} \\
\hline Dry100 & 14.6 & 14.2 & 14.4 & 14.0 & 13.2 & 11.9 & & & & \\
\hline \multicolumn{11}{|c|}{ Body weight } \\
\hline \multicolumn{11}{|c|}{ P intake ( $\%$ of calculated gross requirement) } \\
\hline Dry185 & 205 & 204 & 201 & 194 & 188 & 180 & \multirow[t]{2}{*}{3.1} & \multirow[t]{2}{*}{$<0.001$} & \multirow[t]{2}{*}{$<0.001$} & \multirow[t]{2}{*}{0.006} \\
\hline Dry100 & 128 & 123 & 119 & 118 & 115 & 112 & & & & \\
\hline
\end{tabular}

Dry185: dry cow ration with high P content (3.6 g/kg DM)

Dry100: dry cow ration with $P$ content at requirement $(2.2 \mathrm{~g} / \mathrm{kg} \mathrm{DM})$

SED: standard errors of differences of means for Dry $\times$ Week

Dry: effect of dry cow diet

Dry $\times$ W: effect of interaction of dry cow diet with week

\subsection{Postcalving performance}

Dry matter intake tended to be affected by the $\mathrm{P}$ content of the lactating cow ration over time (Lac $\mathrm{x}$ week interaction, $\mathrm{P}=0.058$ ), due to a slower increase in feed intake in the first 3 weeks for cows on the Lac70 diet (Figure 3.2 or Table 3.4).

Body weight also tended to be affected by the interaction of Lactation diet with week ( $P=0.094$; Table 3.4), with a faster decrease for the Lac70 diet in the first 3 weeks postpartum. Body condition score was unaffected. Milk yield was unaffected by dietary $P$ content during the trial in the first 8 weeks of lactation (Figure 3.3), as well as the calculated energy balance (Table 3.4).

The dietary treatments resulted as expected in a $\mathrm{P}$ intake below calculated requirements for the Lac70 diet with $2.9 \mathrm{~g} \mathrm{P} / \mathrm{kg} \mathrm{DM}$; cows receiving the $3.8 \mathrm{~g} \mathrm{P} / \mathrm{kg}$ DM diet (Lac100) also experienced a calculated negative $P$ balance for the first 4 weeks postpartum turning positive in week 5 . 


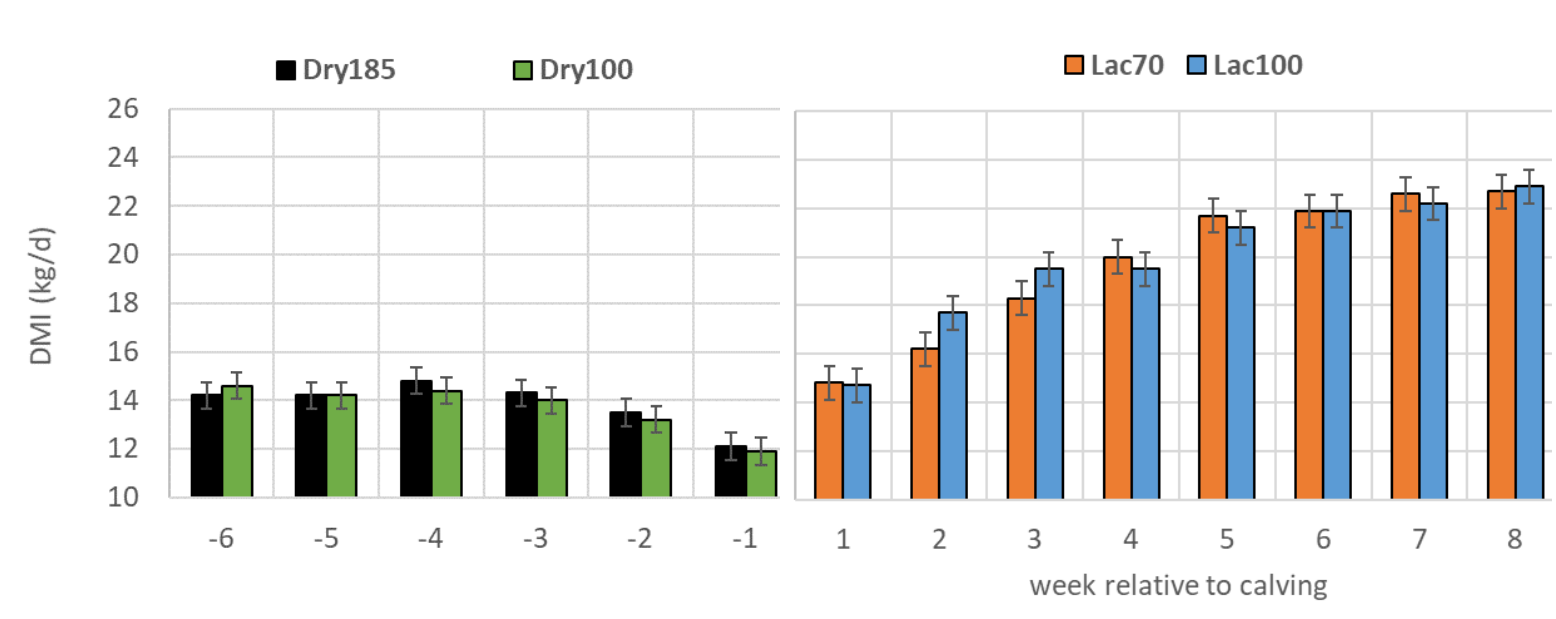

Figure 3.2 Dry matter intake averaged per ration group ( $k g$ DM/cow per day) during dry period (week -6 to -1) and early lactation (week 1 to 8, see also Appendix 2). Error bars representing SED.

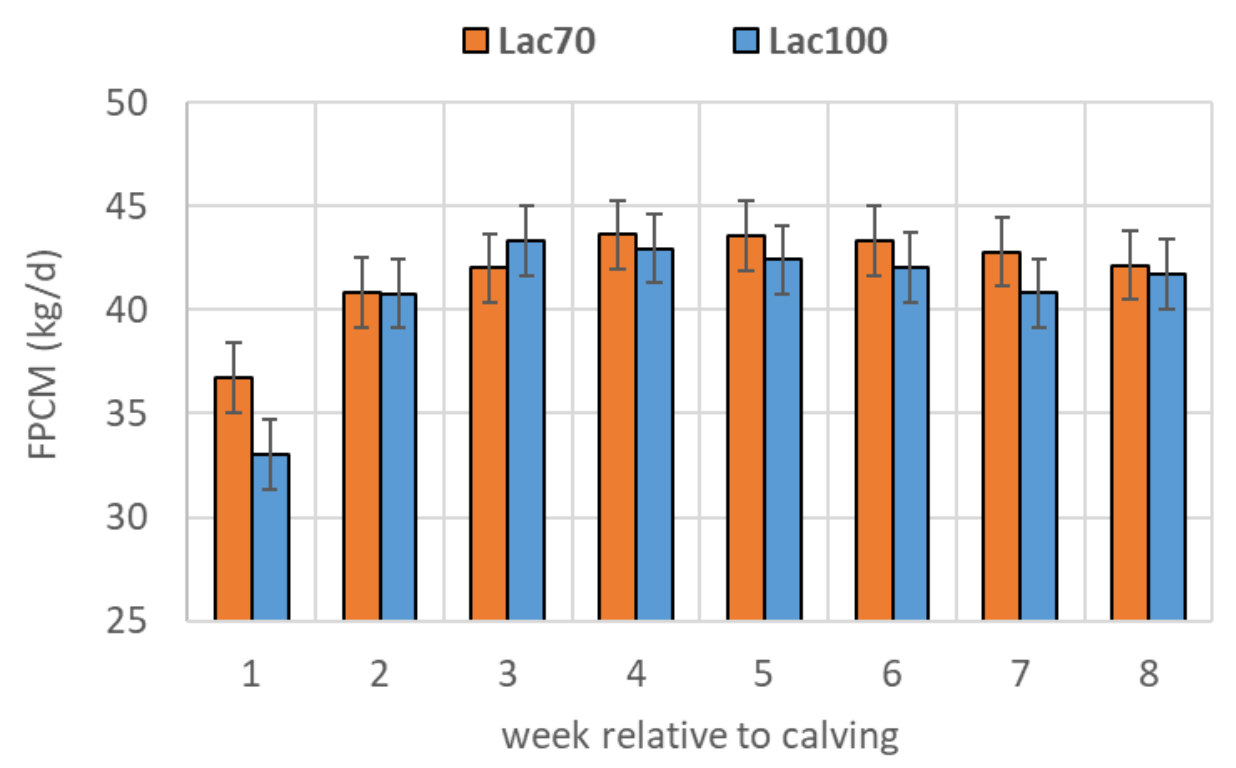

Figure 3.3 Fat- and protein corrected milk yield averaged per lactation ration group ( $\mathrm{kg} / \mathrm{cow}$ per day) in week 1 to 8 after calving (see also Appendix 2). Error bars representing SED. 
Table 3.4 Performance postcalving.

\begin{tabular}{|c|c|c|c|c|c|c|c|c|c|c|c|c|c|}
\hline \multicolumn{8}{|c|}{ Week relative to calving } & \multirow{2}{*}{$\begin{array}{c}\text { SE } \\
\text { D }\end{array}$} & \multicolumn{5}{|c|}{ P-value } \\
\hline 1 & 2 & 3 & 4 & 5 & 6 & 7 & 8 & & Dr & Lac & We & Dry & Lac \\
\hline \multicolumn{14}{|l|}{ DMI (kg/d) } \\
\hline 14 & 15 & 17 & 19 & 20 & 21 & 22 & 22 & \multirow{4}{*}{$\begin{array}{l}0 . \\
97\end{array}$} & \multirow{4}{*}{$\begin{array}{l}0.1 \\
93\end{array}$} & 0.70 & $<0$ & 0.83 & 0.05 \\
\hline 14 & 17 & 19 & 19 & 21 & 22 & 22 & 22 & & & \multirow[t]{3}{*}{6} & \multirow[t]{3}{*}{001} & \multirow[t]{3}{*}{4} & \multirow[t]{3}{*}{8} \\
\hline 15 & 16 & 18 & 20 & 22 & 22 & 23 & 23 & & & & & & \\
\hline 14 & 17 & 20 & 20 & 21 & 21 & 22 & 23 & & & & & & \\
\hline \multicolumn{14}{|c|}{ Body weight (kg) } \\
\hline 71 & 68 & 67 & 67 & 66 & 67 & 67 & 67 & \multirow{4}{*}{$\begin{array}{r}19 \\
.1\end{array}$} & \multirow{4}{*}{$\begin{array}{c}0.5 \\
57\end{array}$} & \multirow{4}{*}{$\begin{array}{c}0.12 \\
3\end{array}$} & & 0.60 & 0.09 \\
\hline 74 & 72 & 71 & 70 & 70 & 70 & 70 & 70 & & & & \multirow{3}{*}{001} & \multirow[t]{3}{*}{8} & \multirow[t]{3}{*}{4} \\
\hline 71 & 69 & 68 & 67 & 68 & 68 & 68 & 68 & & & & & & \\
\hline 71 & 70 & 69 & 68 & 68 & 67 & 68 & 68 & & & & & & \\
\hline \multicolumn{14}{|l|}{ BCS } \\
\hline 3. & 2. & 2. & 2. & 2. & 2. & 2. & 2. & \multirow{4}{*}{$\begin{array}{l}0 . \\
22\end{array}$} & \multirow{4}{*}{$\begin{array}{c}0.4 \\
08\end{array}$} & 0.39 & $<0$ & 0.25 & 0.17 \\
\hline 3. & 3. & 3. & 2. & 2. & 2. & 2. & 2. & & & \multirow[t]{3}{*}{5} & \multirow[t]{3}{*}{001} & \multirow[t]{3}{*}{6} & \multirow[t]{3}{*}{3} \\
\hline 3. & 2. & 2. & 2. & 2. & 2. & 2. & 2. & & & & & & \\
\hline 2. & 2. & 2. & 2. & 2. & 2. & 2. & 2. & & & & & & \\
\hline Milk yield (kg & & & & & & & & & & & & & \\
\hline 29 & 37 & 39 & 42 & 43 & 43 & 43 & 42 & 2. & 0.3 & 0.86 & $<0$ & 0.67 & 0.12 \\
\hline 27 & 38 & 41 & 41 & 43 & 43 & 42 & 42 & 37 & 15 & 4 & 001 & 5 & 6 \\
\hline 30 & 38 & 41 & 44 & 45 & 45 & 45 & 43 & & & & & & \\
\hline 28 & 38 & 42 & 44 & 44 & 44 & 44 & 44 & & & & & & \\
\hline FPCM $(\mathrm{kg} / \mathrm{d})$ & & & & & & & & & & & & & \\
\hline 36 & 40 & 40 & 42 & 42 & 42 & 42 & 41 & 2. & 0.5 & 0.49 & $<0$ & 0.84 & 0.04 \\
\hline 32 & 41 & 44 & 42 & 42 & 42 & 40 & 41 & 36 & 05 & 1 & 001 & 6 & 4 \\
\hline 37 & 41 & 43 & 44 & 44 & 43 & 43 & 43 & & & & & & \\
\hline 33 & 40 & 42 & 43 & 42 & 42 & 41 & 42 & & & & & & \\
\hline Calculated ene & y ba & ice & $/ \mathbf{k g}$ & & & & & & & & & & \\
\hline- & - & - & - & - & - & - & - & 54 & 0.7 & 0.26 & $<0$ & 0.70 & 0.11 \\
\hline- & - & - & - & - & - & - & - & .2 & 74 & 5 & 001 & 5 & 4 \\
\hline- & - & - & - & - & - & - & - & & & & & & \\
\hline- & - & - & - & - & - & - & - & & & & & & \\
\hline$P$ intake $(\%$ of & alcul & ed $\mathbf{g}$ & ss re & irem & t) & & & & & & & & \\
\hline 65 & 66 & 71 & 74 & 78 & 77 & 79 & 82 & 3. & 0.6 & $<0$ & $<0$ & 0.58 & 0.03 \\
\hline 88 & 92 & 92 & 96 & 10 & 10 & 10 & 10 & 6 & 06 & 001 & 001 & 4 & 6 \\
\hline 68 & 69 & 72 & 76 & 80 & 81 & 81 & 82 & & & & & & \\
\hline 85 & 92 & 10 & 98 & 10 & 10 & 10 & 10 & & & & & & \\
\hline
\end{tabular}

D185/L70: dry cow ration Dry185 (high P content, $3.6 \mathrm{~g} / \mathrm{kg} \mathrm{DM}$ ) and lactation ration Lac70 (low P content, $2.9 \mathrm{~g} / \mathrm{kg} \mathrm{DM}$ )

D185/L100: dry cow ration Dry185 (high P content, $3.6 \mathrm{~g} / \mathrm{kg} \mathrm{DM}$ ) and lactation ration Lac100 (P content at requirement, $3.8 \mathrm{~g} / \mathrm{kg}$ DM)

D100/L70: dry cow ration Dry100 (P content at requirement, $2.2 \mathrm{~g} / \mathrm{kg} \mathrm{DM}$ ) and lactation ration Lac70 (low P content, $2.9 \mathrm{~g} / \mathrm{kg}$ DM)

D100/L100: dry cow ration Dry100 (P content at requirement, $2.2 \mathrm{~g} / \mathrm{kg} \mathrm{DM}$ ) and lactation ration Lac100 (P content at requirement, $3.8 \mathrm{~g} / \mathrm{kg}$ DM)

Dry: effect of $P$ content of dry cow ration

Lac: effect of $P$ content of lactation cow ration

Interaction of Dry $x$ Lac and Dry $x$ Lac $x$ Week were not significant for any of the parameters, but were kept in the model 


\subsection{Milk composition}

Fat, protein and lactose content were not significantly affect by the dietary treatments (Table 3.5). Daily yield of fat and lactose was affected (Lac $\times$ week interaction, $P<0.05$; Table 3.5), mainly due to a difference in the first week of lactation (Figure 3.4).

Milk urea content was higher in milk of cows on the diet with $2.9 \mathrm{~g} \mathrm{P} / \mathrm{kg}$ DM compared with the diet with $3.8 \mathrm{~g} \mathrm{P} / \mathrm{kg} \mathrm{DM}$ (Table 3.5; Figure 3.4C). This may be related to the lower dry matter intake in the same period.
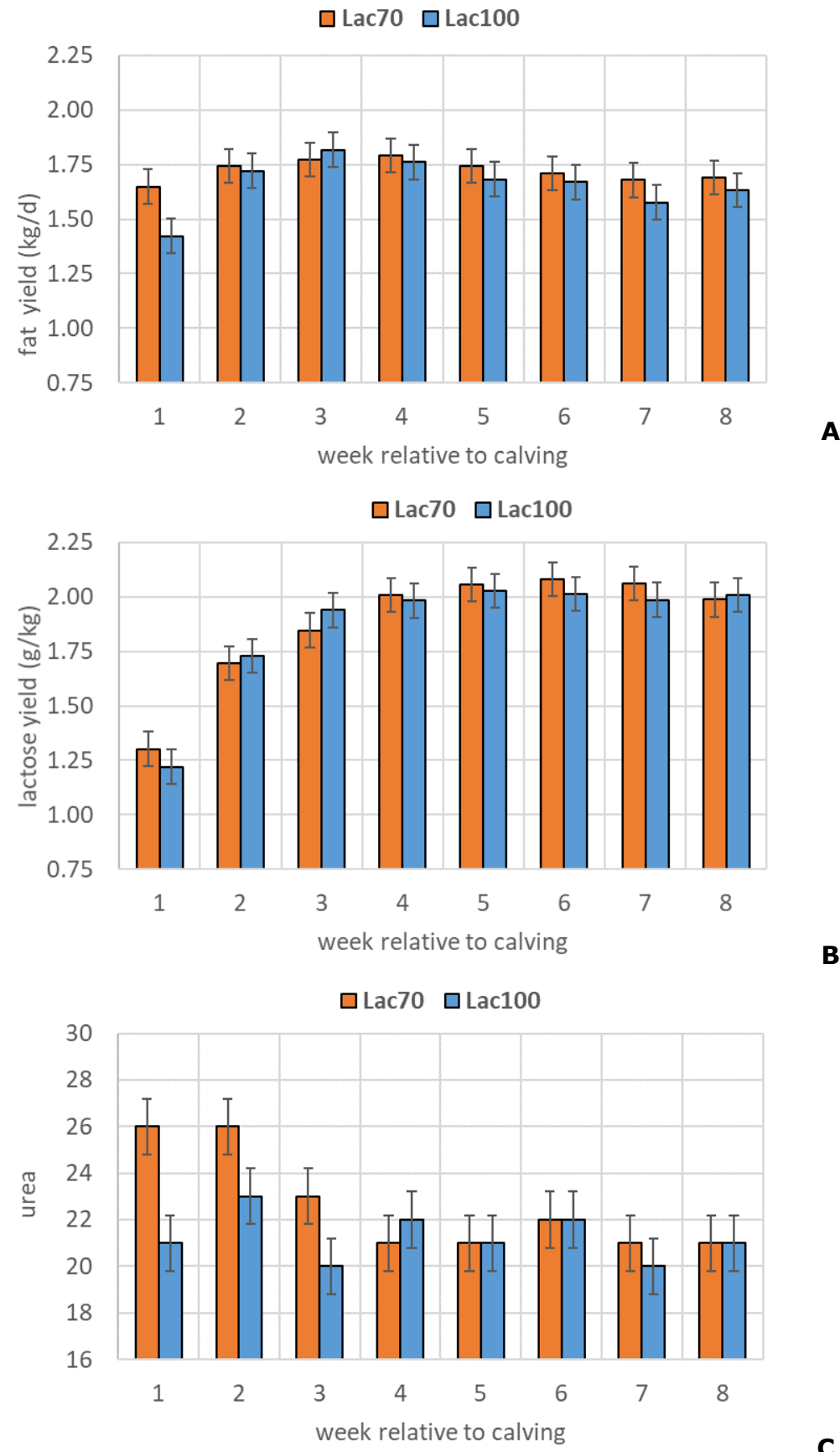

B

Figure 3.4 Fat yield ( $\mathrm{kg} / \mathrm{cow}$ per day, $\mathrm{A})$, lactose yield $(\mathrm{kg} / \mathrm{cow}$ per day, $B$ ) and milk urea content $(\mathrm{mg} / \mathrm{dl}, \mathrm{C})$ averaged per lactation ration group in week 1 to 8 after calving (error bars representing $S E D)$. 
Table 3.5 Milk composition

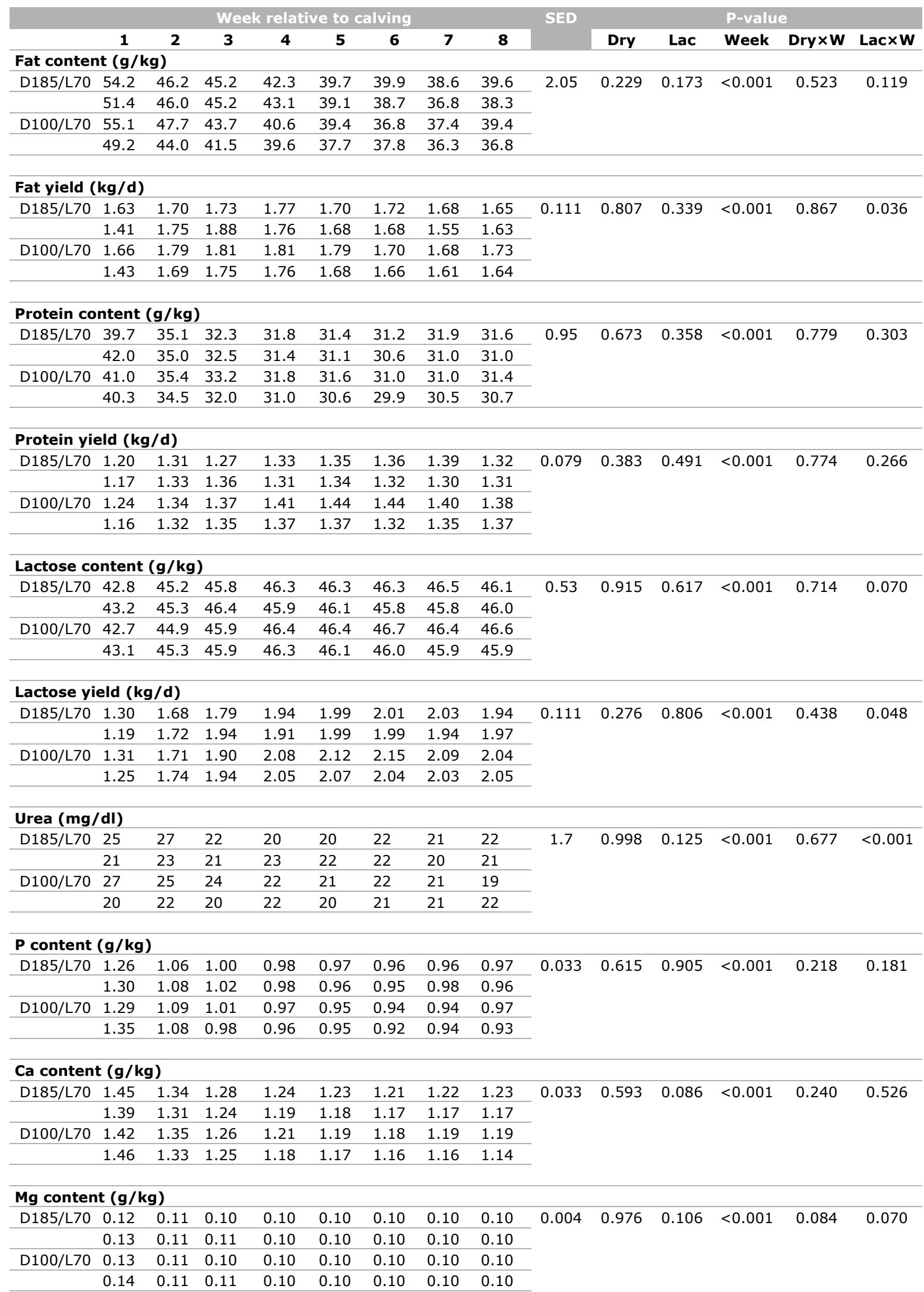

D185/L70: dry cow ration Dry185 (high P content, $3.6 \mathrm{~g} / \mathrm{kg} \mathrm{DM}$ ) and lactation ration Lac70 (low P content, $2.9 \mathrm{~g} / \mathrm{kg} \mathrm{DM}$ )

D185/L100: dry cow ration Dry185 (high P content, $3.6 \mathrm{~g} / \mathrm{kg} \mathrm{DM}$ ) and lactation ration Lac100 (P content at requirement, $3.8 \mathrm{~g} / \mathrm{kg} \mathrm{DM}$ )

D100/L70: dry cow ration Dry100 (P content at requirement, $2.2 \mathrm{~g} / \mathrm{kg} \mathrm{DM}$ ) and lactation ration Lac70 (low P content, $2.9 \mathrm{~g} / \mathrm{kg} \mathrm{DM}$ )

D100/L100: dry cow ration Dry100 (P content at requirement, $2.2 \mathrm{~g} / \mathrm{kg} \mathrm{DM}$ ) and lactation ration Lac100 (P content at requirement, $3.8 \mathrm{~g} / \mathrm{kg}$ DM)

Dry: effect of $P$ content of dry cow ration

Lac: effect of $P$ content of lactation cow ration

Interaction of Dry $\mathrm{x}$ Lac and Dry $\mathrm{x}$ Lac $\mathrm{x}$ Week were not significant for any of the parameters 
The concentration of the three minerals $\mathrm{P}, \mathrm{Ca}$ and $\mathrm{Mg}$ in milk was highest in week 1 postpartum and decreased in 3-4 weeks to a relatively stable level. The average concentration of $P$ in milk was 0.97 $\mathrm{g} / \mathrm{kg}$ milk in week 5 to 8 postpartum; milk $\mathrm{P}$ concentration was not affected by the dietary concentration of $P$ (Table 3.5, Figure 3.5). Milk Ca however tended to be higher for cows receiving the low $\mathrm{P}$ diet (Lac70) as shown in Figure 3.5 and Table $3.5(\mathrm{P}=0.086)$.
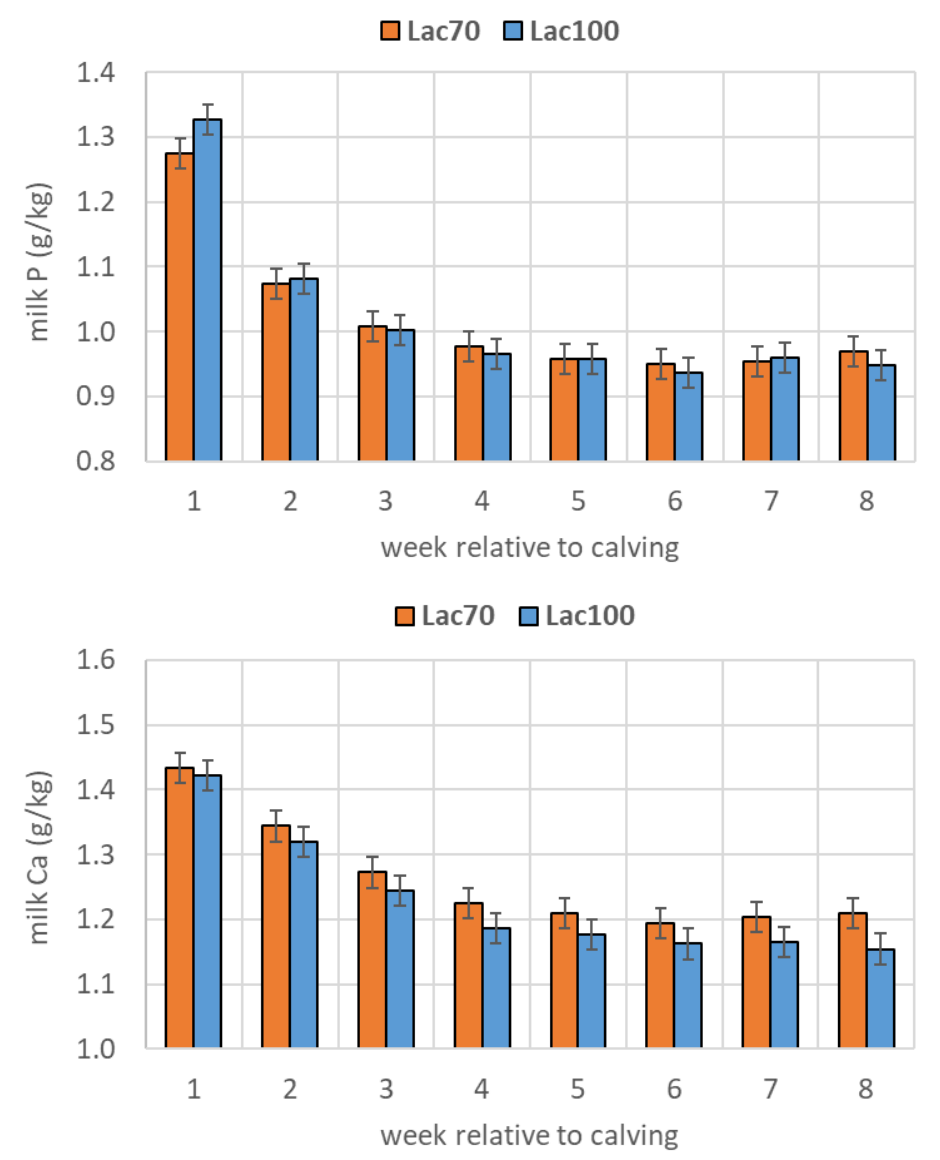

A

B

Figure 3.5 Milk $P$ concentration $(A)$ and Ca concentration $(B)$ in $\mathrm{g} / \mathrm{kg}$ milk, averaged per lactation ration group in week 1 to 8 after calving (error bars representing SED). 


\subsection{Blood parameters}

In the dry period, plasma $\mathrm{P}$ concentration did not differ between cows fed a dry cow diet containing $2.2 \mathrm{~g} \mathrm{P} / \mathrm{kg}$ DM (Dry100) compared with a high P diet with $3.6 \mathrm{~g} \mathrm{P} / \mathrm{kg} \mathrm{DM}$ (Dry185). The Ca concentration however was slightly lower for animals on the high $\mathrm{P}$ diet, resulting in a the lower Ca to $P$ ratio $(P<0.05$; Table 3.6) Ca concentration was still within the reference range for normocalcemia. Plasma NEFA and BHB are relatively low, suggesting little lipid mobilisation prepartum (Table 3.6). Concentrations of vitamin $\mathrm{D}_{3}$ and PTH were not different between treatments, but CTX concentration increases towards calving for cows on a high P diet (Dry185), indicating bone mobilisation (Dry $\times$ week interaction, $\mathrm{P}<0.01$; Table 3.6)

Table 3.6 Blood results prepartum.

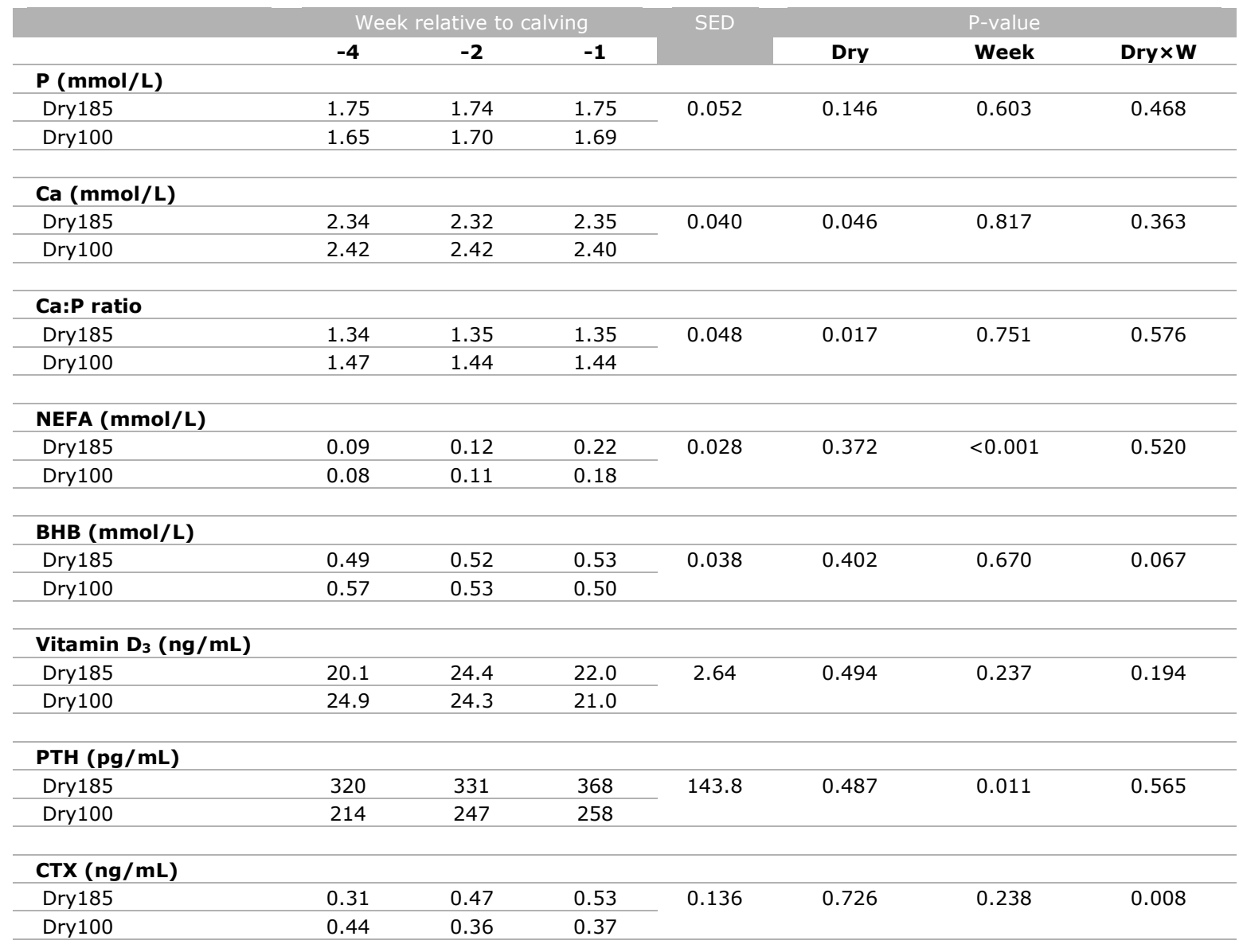

Dry185: dry cow ration with high P content ( $3.6 \mathrm{~g} / \mathrm{kg} \mathrm{DM})$

Dry100: dry cow ration with $P$ content at requirement $(2.2 \mathrm{~g} / \mathrm{kg} \mathrm{DM})$

Dry: effect of $P$ content of dry cow ration

Interestingly, the dry cow diet also affected plasma parameters after calving. Cows on the dry cow diet with $3.6 \mathrm{~g} \mathrm{P} / \mathrm{kg}$ DM (Dry185) had on average a lower plasma P concentration (1.31 vs. 1.40 $\mathrm{mmol} / \mathrm{L}$ ) and a lower plasma Ca concentration (2.20 vs. $2.29 \mathrm{mmol} / \mathrm{L}$ ) postpartum than cows on the dry cow diet Dry100 with $2.2 \mathrm{~g} \mathrm{P} / \mathrm{kg} \mathrm{DM}(\mathrm{P}<0.05$, Table 3.7 and Figure 3.6).

Feeding a high $\mathrm{P}$ diet in the dry period seems to be negatively affecting the Ca and $\mathrm{P}$ homeostasis compared with the normocalcemic dry cow ration, as was also shown in the study of Cohrs et al.

(2018).

Plasma P gives an indication of the non-bone, extracellular $\mathrm{P}$ status but about $99 \%$ of non-bone $\mathrm{P}$ is present intracellular (Grünberg, 2014). Changes in the balance between intracellular and extracellular $\mathrm{P}$ may occur suddenly and affect plasma $\mathrm{P}$. The decrease in plasma $\mathrm{P}$ around parturition as found in this study (from $1.7 \mathrm{mmol} / \mathrm{L}$ precalving to $1.2 \mathrm{mmol} / \mathrm{L}$ at d0) is a common phenomenon in dairy cattle. It is not only due to the loss of $\mathrm{P}$ through milk production, as the same drop around parturition also occurs in mastectomized cows (Goff et al., 2002). The decrease may be related to the reduction in 
feed intake around calving, an increase in plasma corticosteroids and more generally a redistribution of intracellular and extracellular P (Grünberg, 2014).

Table 3.7 Blood results postpartum

\begin{tabular}{|c|c|c|c|c|c|c|c|c|c|c|c|c|c|c|c|}
\hline & \multicolumn{9}{|c|}{ Day relative to calving } & \multirow[t]{2}{*}{ SED } & \multicolumn{5}{|c|}{ P-value } \\
\hline & $\mathbf{0}$ & 1 & 2 & 3 & 7 & 14 & $\mathbf{2 1}$ & 28 & 56 & & Dry & Lac & Week & Dry $\times w$ & Lac $\times W$ \\
\hline \multicolumn{16}{|c|}{ P (mmol/L) } \\
\hline D185/L70 & 1.32 & 1.38 & 1.36 & 1.29 & 0.75 & 0.98 & 1.24 & 1.34 & 1.31 & \multirow[t]{4}{*}{0.104} & \multirow[t]{4}{*}{0.026} & \multirow[t]{4}{*}{$<0.001$} & \multirow[t]{4}{*}{$<0.001$} & \multirow[t]{4}{*}{0.306} & \multirow[t]{4}{*}{$<0.001$} \\
\hline & 1.17 & 1.21 & 1.30 & 1.34 & 1.49 & 1.54 & 1.47 & 1.52 & 1.51 & & & & & & \\
\hline \multirow[t]{2}{*}{ D100/L70 } & 1.23 & 1.28 & 1.22 & 1.14 & 1.11 & 1.27 & 1.39 & 1.36 & 1.35 & & & & & & \\
\hline & 1.16 & 1.41 & 1.63 & 1.64 & 1.54 & 1.54 & 1.60 & 1.64 & 1.64 & & & & & & \\
\hline \multirow[t]{2}{*}{ D185/L70 } & 1.85 & 1.89 & 2.12 & 2.38 & 2.34 & 2.42 & 2.40 & 2.28 & 2.47 & \multirow[t]{4}{*}{0.091} & \multirow[t]{4}{*}{0.004} & \multirow[t]{4}{*}{0.010} & \multirow[t]{4}{*}{$<0.001$} & \multirow[t]{4}{*}{0.388} & \multirow[t]{4}{*}{0.321} \\
\hline & 1.81 & 1.74 & 2.02 & 2.20 & 2.30 & 2.34 & 2.33 & 2.33 & 2.29 & & & & & & \\
\hline \multirow[t]{2}{*}{ D100/L70 } & 2.05 & 2.16 & 2.25 & 2.37 & 2.39 & 2.38 & 2.44 & 2.44 & 2.44 & & & & & & \\
\hline & 1.93 & 1.88 & 2.07 & 2.39 & 2.28 & 2.40 & 2.45 & 2.40 & 2.44 & & & & & & \\
\hline
\end{tabular}

\section{Ca:P ratio}

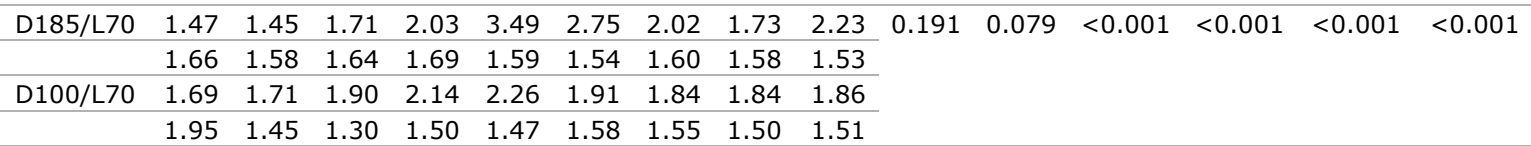

NEFA (mmol/L)

\begin{tabular}{|c|c|c|c|c|c|c|c|c|c|c|c|c|c|c|c|}
\hline \multirow[t]{2}{*}{ D185/L70 } & 0.94 & 0.93 & 0.67 & 0.65 & 0.59 & 0.44 & 0.37 & 0.25 & 0.14 & \multirow{4}{*}{\multicolumn{2}{|c|}{0.110}} & \multirow[t]{4}{*}{0.611} & \multirow[t]{4}{*}{$<0.001$} & \multirow[t]{4}{*}{0.504} & \multirow[t]{4}{*}{0.527} \\
\hline & 0.99 & 0.74 & 0.67 & 0.69 & 0.56 & 0.39 & 0.38 & 0.32 & 0.17 & & & & & & \\
\hline \multirow[t]{2}{*}{ D100/L70 } & 0.78 & 0.66 & 0.71 & 0.65 & 0.62 & 0.39 & 0.38 & 0.26 & 0.21 & & & & & & \\
\hline & 0.92 & 0.67 & 0.66 & 0.59 & 0.47 & 0.28 & 0.29 & 0.25 & 0.13 & & & & & & \\
\hline
\end{tabular}

\begin{tabular}{|c|c|c|c|c|c|c|c|c|c|c|c|c|c|c|c|}
\hline \multicolumn{16}{|c|}{ BHB (mmol/L) } \\
\hline \multirow[t]{2}{*}{ D185/L70 } & 0.67 & 0.87 & 1.07 & 0.79 & 0.90 & 0.68 & 0.69 & 0.70 & 0.71 & \multirow[t]{4}{*}{0.150} & \multirow[t]{4}{*}{0.774} & \multirow[t]{4}{*}{0.260} & \multirow[t]{4}{*}{0.004} & \multirow[t]{4}{*}{0.365} & \multirow[t]{4}{*}{0.156} \\
\hline & 0.62 & 0.80 & 0.88 & 0.83 & 0.82 & 0.71 & 0.86 & 0.99 & 0.80 & & & & & & \\
\hline \multirow[t]{2}{*}{ D100/L70 } & 0.53 & 0.65 & 0.73 & 0.82 & 1.01 & 0.66 & 0.71 & 0.66 & 0.81 & & & & & & \\
\hline & 0.54 & 0.83 & 0.89 & 0.80 & 0.80 & 0.93 & 0.82 & 0.90 & 0.99 & & & & & & \\
\hline
\end{tabular}

\begin{tabular}{|c|c|c|c|c|c|c|c|c|c|c|c|c|c|c|c|}
\hline \multicolumn{16}{|c|}{ Vitamin $D_{3}(\mathrm{ng} / \mathrm{L})$} \\
\hline \multirow[t]{2}{*}{ D185/L70 } & 20.2 & 21.3 & 19.8 & 23.0 & 22.6 & 20.6 & 19.6 & 18.3 & 16.0 & \multirow[t]{3}{*}{4.65} & \multirow[t]{3}{*}{0.673} & \multirow[t]{3}{*}{0.621} & \multirow[t]{3}{*}{0.060} & \multirow[t]{3}{*}{0.557} & \multirow[t]{3}{*}{0.433} \\
\hline & 21.5 & 25.5 & 24.0 & 23.4 & 21.1 & 20.5 & 19.2 & 20.1 & 19.1 & & & & & & \\
\hline D100/L70 & 21.3 & 34.1 & 20.8 & 34.0 & 21.2 & 20.1 & 18.6 & 18.0 & 17.3 & & & & & & \\
\hline
\end{tabular}

\begin{tabular}{|c|c|c|c|c|c|c|c|c|c|c|c|c|c|c|c|}
\hline \multicolumn{16}{|c|}{ PTH (pg/mL) } \\
\hline \multirow[t]{2}{*}{ D185/L70 } & 399 & 374 & 235 & 211 & 127 & 83 & 85 & 102 & 147 & \multirow[t]{4}{*}{138.7} & \multirow[t]{4}{*}{0.632} & \multirow[t]{4}{*}{0.909} & \multirow[t]{4}{*}{$<0.001$} & \multirow[t]{4}{*}{0.305} & \multirow[t]{4}{*}{0.770} \\
\hline & 611 & 520 & 501 & 405 & 250 & 210 & 176 & 216 & 355 & & & & & & \\
\hline \multirow[t]{2}{*}{ D100/L70 } & 492 & 502 & 422 & 363 & 280 & 196 & 160 & 150 & 202 & & & & & & \\
\hline & 265 & 269 & 233 & 150 & 138 & 112 & 103 & 105 & 95 & & & & & & \\
\hline
\end{tabular}

\begin{tabular}{|c|c|c|c|c|c|c|c|c|c|c|c|c|c|c|c|}
\hline \multicolumn{16}{|c|}{ CTX (ng/mL) } \\
\hline \multirow[t]{2}{*}{ D185/L70 } & 1.08 & 1.26 & 1.19 & 1.28 & 1.99 & 2.64 & 2.97 & 3.14 & 3.12 & \multirow[t]{4}{*}{0.340} & \multirow[t]{4}{*}{0.160} & \multirow[t]{4}{*}{0.007} & \multirow[t]{4}{*}{$<0.001$} & \multirow[t]{4}{*}{0.122} & \multirow[t]{4}{*}{$<0.001$} \\
\hline & 0.92 & 0.95 & 1.27 & 1.24 & 1.16 & 1.55 & 1.62 & 1.92 & 2.11 & & & & & & \\
\hline \multirow[t]{2}{*}{ D100/L70 } & 0.95 & 1.15 & 1.00 & 1.14 & 1.42 & 2.42 & 2.52 & 2.52 & 2.07 & & & & & & \\
\hline & 0.71 & 1.00 & 0.99 & 0.88 & 1.11 & 1.46 & 1.75 & 1.77 & 1.64 & & & & & & \\
\hline
\end{tabular}

D185/L70: dry cow ration Dry185 (high P content, $3.6 \mathrm{~g} / \mathrm{kg} \mathrm{DM}$ ) and lactation ration Lac70 (low P content, $2.9 \mathrm{~g} / \mathrm{kg} \mathrm{DM)}$ D185/L100: dry cow ration Dry185 (high P content, $3.6 \mathrm{~g} / \mathrm{kg} \mathrm{DM}$ ) and lactation ration Lac100 (P content at requirement, $3.8 \mathrm{~g} / \mathrm{kg} \mathrm{DM}$ ) D100/L70: dry cow ration Dry100 (P content at requirement, $2.2 \mathrm{~g} / \mathrm{kg} \mathrm{DM}$ ) and lactation ration Lac70 (low P content, $2.9 \mathrm{~g} / \mathrm{kg} \mathrm{DM}$ ) D100/L100: dry cow ration Dry100 (P content at requirement, $2.2 \mathrm{~g} / \mathrm{kg} \mathrm{DM}$ ) and lactation ration Lac100 ( $\mathrm{P}$ content at requirement, $3.8 \mathrm{~g} / \mathrm{kg}$ DM) Dry: effect of $\mathrm{P}$ content of dry cow ration

Lac: effect of $\mathrm{P}$ content of lactation cow ration

Interaction of Dry $x$ Lac is not significant for any of the parameters; interaction Dry $x$ Lac $\times$ Week is only significant for plasma $P(P=0.002)$

The dietary $\mathrm{P}$ concentration of the lactation diet also affected plasma $\mathrm{P}$ and Ca concentration. Cows consuming the low P lactation diet (Lac70) with $2.9 \mathrm{~g} \mathrm{P} / \mathrm{kg}$ DM had on average a lower plasma P concentration ( 1.24 vs. $1.46 \mathrm{mmol} / \mathrm{L}$ ) and a higher plasma Ca concentration (2.28 vs. $2.20 \mathrm{mmo} / \mathrm{L})$ in the first 8 weeks of lactation than cows consuming the high $\mathrm{P}$ lactation diet with $3.8 \mathrm{~g} \mathrm{P} / \mathrm{kg}$ DM (Lac100). For plasma $P$, the interaction of the dry cow diet $\times$ lactation diet $\times$ week was significant with the strongest decrease after calving for cows receiving the Dry185 with Lac100 combination, and most 
stable plasma $\mathrm{P}$ for cows receiving the Dry100 with Lac100 combination (see also Appendix 2, Figure A2.3).

The plasma Ca to $\mathrm{P}$ ratio was affected most clearly with a relatively stable ratio for cows on the high $\mathrm{P}$ diet, while cows on the low $\mathrm{P}$ diet had an increased $\mathrm{Ca}$ to $\mathrm{P}$ ratio with highest level 7 days postpartum.

Vitamin $\mathrm{D}_{3}$ and PTH do not seem to be good indicators for changes in $\mathrm{P}$ metabolism postpartum. In contrast to the changes in plasma $\mathrm{P}$ and $\mathrm{Ca}$, vitamin $\mathrm{D}_{3}$ and $\mathrm{PTH}$ concentration are not affected by the dietary treatments prepartum or postpartum (Table 3.7). In the study of Cohrs et al. (2018), PTH was significantly higher in control cows compared with P-deprived cows. In this study however, Pdeprivation was started in the dry period and continued into the lactation, which may be different in our study were all dry cows were fed above calculated $\mathrm{P}$ requirements.

The effect of the dietary changes on bone mobilisation is shown in CTX concentration, which is increased for animals on Lac70, the low P diet postpartum (Table 3.7).

Postpartum, plasma NEFA and BHB do not seem to be affected by the dietary treatments (Table 3.7). This was expected, as energy balance does not seem te be affected either (Table 3.3), suggesting no strong differences in lipid mobilisation due to the dietary treatments.
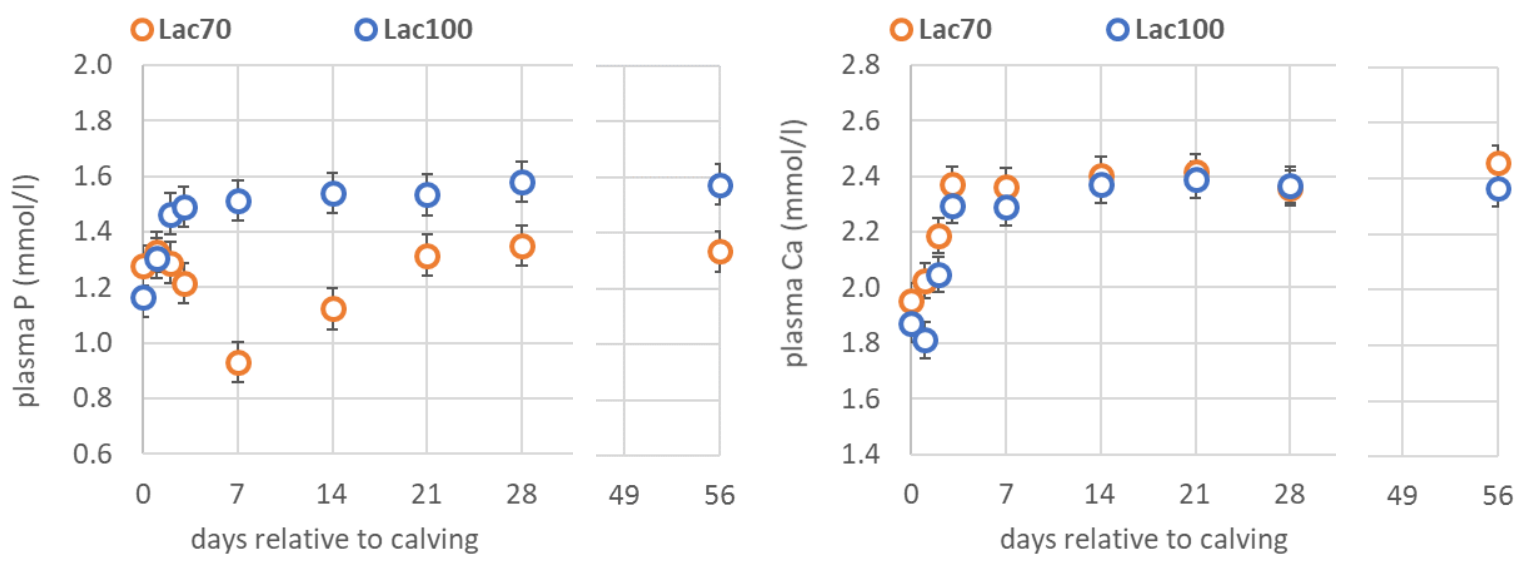

A
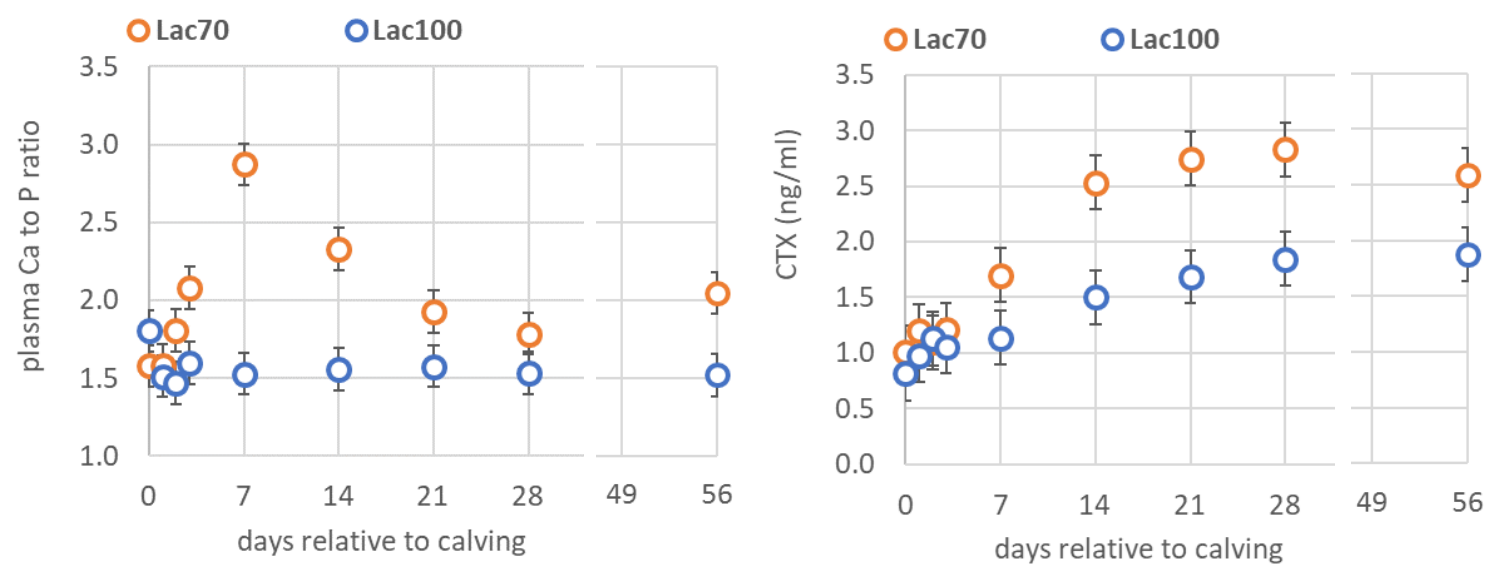

C

Figure 3.6 Plasma $P$ concentration ( $\mathrm{mmol} / \mathrm{L} ; A)$, Ca concentration ( $\mathrm{mmol} / \mathrm{L} ; B)$, Ca to $P$ ratio and plasma CTX concentration $(\mathrm{ng} / \mathrm{mL}, \mathrm{D})$, averaged per lactation ration group for blood sampling moments on day $0,1,2,3,7,14,21,28$ and 56 after calving (error bars representing SED). 


\subsection{Health}

In case a cow showed at least 2 out of 3 symptoms of clinical hypocalcemia around calving (i.e. 'recumbency / not able to stand', 'cold ears' and 'low rumen fill with no contractions'), animal caretakers treated that cow intravenously with a CaMg infusion $(450 \mathrm{~mL} 1.65 \% \mathrm{Ca}$ and $0.95 \% \mathrm{Mg}$ ).

During the trial, 15 cows were treated for clinical hypocalcemia (Table 3.8a) and all treatments were successful; cows recovered after single treatment. The incidence of clinical hypocalcemia in the four treatment groups (Table 3.8a) or between the experimental diets (Table 3.8b) was not significantly different. The total incidence of cows treated for clinical symptoms of hypocalcemia in this trial $(25 \%)$ seems relatively high for common dairy practice; it is however comparable to the average incidence in multiparous cows at the research farm in 2016 and 2017 (22\%).

When looking at the blood plasma Ca levels measured at d0 and d1, a total of 21 cows (36\%) had Ca levels below $1.8 \mathrm{mmol} / \mathrm{L}$ - with or without clinical signs of hypocalcemia (Table 3.8). The number of animals with low plasma Ca values (either below $2.0,1.9$ or $1.8 \mathrm{mmol} / \mathrm{L}$ ) was significantly lower in treatment group D100/L70 compared to the other three treatment groups. This suggests that a low level of $\mathrm{P}$ in dairy cow rations in the transition period (in the dry period as well as lactation) reduces the risk for hypocalcemia (Table 3.8a; P $<0.05$ ). The same result was found for the incidence of low plasma $\mathrm{Ca}$ on the two dry cow diets as well as the incidence with the two lactation diets (Table 3.8b). The effect of the lactation diets cannot have been large however, as cows were provided the dry cow diets until calving. Hypocalcemia was defined at $\mathrm{d} 0$ and $\mathrm{d} 1$, when cows had consumed the lactation diets for only 1 to 2 days.

Table 3.8a Hypocalcemia incidence per treatment group including $P$-value for chi-square analysis. For the various cut-off levels of plasma Ca defining hypocalcemia, the number of cows that was treated for clinical signs within this group of animals is shown between brackets.

\begin{tabular}{|c|c|c|c|c|c|}
\hline & $\begin{array}{l}\text { D185/L70 } \\
(n=14)\end{array}$ & $\begin{array}{l}\text { D185/L100 } \\
(n=15)\end{array}$ & $\begin{array}{l}D 100 / L 70 \\
(n=15)\end{array}$ & $\begin{array}{l}\text { D100/L100 } \\
(n=15)\end{array}$ & P-value \\
\hline \multicolumn{6}{|l|}{ Clinical hypocalcemia } \\
\hline \multicolumn{6}{|l|}{ Total hypocalcemic animals } \\
\hline Plasma Ca $<2.0 \mathrm{mmol} / \mathrm{L}$ & $12(4)$ & $13(5)$ & $5(1)$ & $12(4)$ & 0.003 \\
\hline Plasma Ca $<1.8 \mathrm{mmol} / \mathrm{L}$ & $5(3)$ & $7(4)$ & $1(1)$ & $8(2)$ & 0.040 \\
\hline \multicolumn{6}{|c|}{ D185/L70: dry cow ration Dry185 (high P content, $3.6 \mathrm{~g} / \mathrm{kg} \mathrm{DM}$ ) and lactation ration Lac70 (low P content, $2.9 \mathrm{~g} / \mathrm{kg} \mathrm{DM}$ ) } \\
\hline \multirow{2}{*}{\multicolumn{6}{|c|}{$\begin{array}{l}\text { D185/L100: dry cow ration Dry185 (high P content, } 3.6 \mathrm{~g} / \mathrm{kg} \mathrm{DM} \text { ) and lactation ration Lac100 (P content at requirement, } 3.8 \mathrm{~g} / \mathrm{kg} \mathrm{DM} \text { ) } \\
\text { D100/L70: dry cow ration Dry100 (P content at requirement, } 2.2 \mathrm{~g} / \mathrm{kg} \text { DM) and lactation ration Lac70 (low P content, } 2.9 \mathrm{~g} / \mathrm{kg} \text { DM) }\end{array}$}} \\
\hline & & & & & \\
\hline \multicolumn{6}{|c|}{ D100/L100: dry cow ration Dry100 (P content at requirement, $2.2 \mathrm{~g} / \mathrm{kg} \mathrm{DM}$ ) and lactation ration Lac100 ( $\mathrm{P}$ content at requirement, $3.8 \mathrm{~g} / \mathrm{kg}$} \\
\hline
\end{tabular}

Table 3.8b Hypocalcemia incidence per diet including $P$-value for chi-square analysis. For the various cut-off levels of plasma Ca defining hypocalcemia, the number of cows that was treated for clinical signs within this group of animals is shown between brackets.

\begin{tabular}{|c|c|c|c|c|c|c|}
\hline & $\begin{array}{l}\text { Dry } 100 \\
(n=30)\end{array}$ & $\begin{array}{l}\text { Dry } 185 \\
(n=29)\end{array}$ & P-value & $\begin{array}{c}\text { Lac70 } \\
(n=29)\end{array}$ & $\begin{array}{l}\text { Lac100 } \\
(n=30)\end{array}$ & P-value \\
\hline \multicolumn{7}{|l|}{ Clinical hypocalcemia } \\
\hline \multicolumn{7}{|l|}{ Total hypocalcemic animals } \\
\hline Plasma $\mathrm{Ca}<2.0 \mathrm{mmol} / \mathrm{L}$ & $17(5)$ & $25(9)$ & 0.012 & $17(5)$ & $25(9)$ & 0.036 \\
\hline Plasma Ca $<1.8 \mathrm{mmol} / \mathrm{L}$ & $9(3)$ & $12(7)$ & 0.361 & $6(4)$ & $15(6)$ & 0.019 \\
\hline \multicolumn{7}{|c|}{ Dry100: dry cow ration with P content at requirement $(2.2 \mathrm{~g} / \mathrm{kg} \mathrm{DM})$} \\
\hline \multicolumn{7}{|c|}{ Dry 185: dry cow ration with high P content ( $3.6 \mathrm{~g} / \mathrm{kg} \mathrm{DM})$} \\
\hline \multicolumn{7}{|c|}{ Lac70: lactation ration with low P content $(2.9 \mathrm{~g} / \mathrm{kg} \mathrm{DM})$} \\
\hline Lac100: lactation ration with $\mathrm{P}$ & ent $(3.8 \mathrm{~g} / \mathrm{kg}$ & & & & & \\
\hline
\end{tabular}

As a common finding, plasma $P$ is reported to be low in cows with clinical signs of hypocalcemia in practice. When comparing plasma $\mathrm{P}$ concentrations of the 15 treated cows around calving with the non-treated animals, a low plasma P may be noted at d0 (Figure 3.7B). This is likely related to the 
reduced feed intake accompanying the clinical hypocalcemia around d0 (Figure 3.7A) and does not seem to be involved in the mechanism of periparturient paresis. Precalving, plasma Ca is already decreasing while plasma $\mathrm{P}$ is stable or even higher for the group of cows with clinical hypocalcemia.
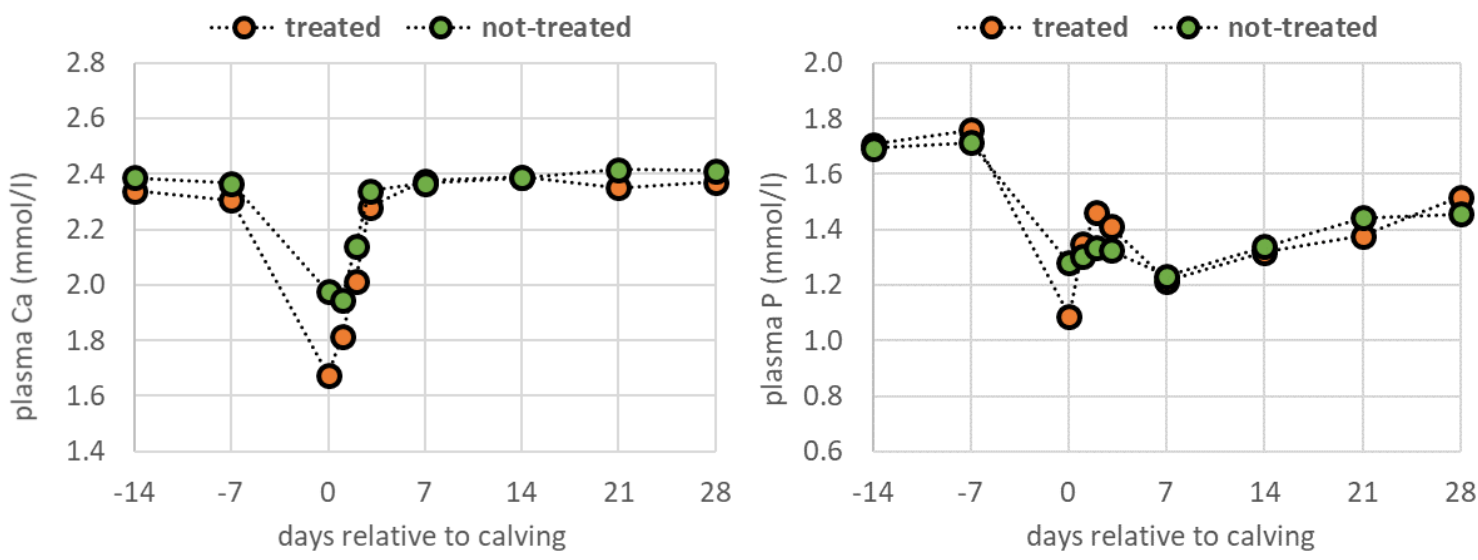

A

B

Figure 3.7 Plasma P concentration ( $\mathrm{mmol} / \mathrm{L} ; A)$ and Ca concentration $(\mathrm{mmol} / \mathrm{L} ; B)$ averaged for cows treated for clinical hypocalcemia compared with the non-treated cows for blood sampling moments 2 and 1 week before calving as well as on day $0,1,2,3,7,14,21$ and 28 after calving.

For other diseases, no differences were found between treatment groups ( $P>0.10$; Table 3.9).

Table 3.9 Incidence of diseases other than hypocalcemia, per treatment group $(n=15)$

\begin{tabular}{|c|c|c|c|c|}
\hline & D 185/L70 & D185/L100 & D100/L70 & D100/L100 \\
\hline \multicolumn{5}{|l|}{ Generalized conditions } \\
\hline Fever & 1 & 2 & 2 & 1 \\
\hline \multicolumn{5}{|l|}{ Udder health } \\
\hline Clinical mastitis & 1 & 1 & 1 & 2 \\
\hline \multicolumn{5}{|l|}{ Reproduction* } \\
\hline Retained placenta & 1 & 1 & 2 & 0 \\
\hline Acute endometritis ( $<14 d$, fever) & 3 & 1 & 1 & 0 \\
\hline Chronic endometritis (>14d) & 7 & 6 & 4 & 8 \\
\hline Pyometra & 3 & 2 & 1 & 0 \\
\hline Cystic Ovaries & 1 & 1 & 0 & 1 \\
\hline \multicolumn{5}{|l|}{ Claw health } \\
\hline Laminitis & 1 & 0 & 0 & 1 \\
\hline Digital dermatitis & 0 & 2 & 0 & 2 \\
\hline Interdigital dermatitis & 0 & 0 & 0 & 1 \\
\hline Interdigital phlegmona & 0 & 1 & 0 & 0 \\
\hline White line disease & 0 & 0 & 0 & 1 \\
\hline Sole ulcer & 0 & 1 & 0 & 0 \\
\hline \multicolumn{5}{|l|}{ Intestines } \\
\hline Abomasal displacement & 0 & 1 & 0 & 0 \\
\hline Hardware disease & 1 & 0 & 0 & 0 \\
\hline Diarrhea & 0 & 0 & 1 & 0 \\
\hline Indigestion & 0 & 0 & 0 & 1 \\
\hline \multicolumn{5}{|c|}{ D185/L70: dry cow ration Dry185 (high P content, $3.6 \mathrm{~g} / \mathrm{kg} \mathrm{DM}$ ) and lactation ration Lac70 (low P content, $2.9 \mathrm{~g} / \mathrm{kg} \mathrm{DM}$ ) } \\
\hline \multicolumn{5}{|c|}{ D185/L100: dry cow ration Dry185 (high P content, $3.6 \mathrm{~g} / \mathrm{kg} \mathrm{DM}$ ) and lactation ration Lac100 (P content at requirement, $3.8 \mathrm{~g} / \mathrm{kg} \mathrm{DM}$ ) } \\
\hline \multicolumn{5}{|c|}{ D100/L70: dry cow ration Dry100 (P content at requirement, $2.2 \mathrm{~g} / \mathrm{kg} \mathrm{DM}$ ) and lactation ration Lac70 (low P content, $2.9 \mathrm{~g} / \mathrm{kg}$ DM) } \\
\hline \multicolumn{5}{|c|}{ D100/L100: dry cow ration Dry100 (P content at requirement, $2.2 \mathrm{~g} / \mathrm{kg} \mathrm{DM}$ ) and lactation ration Lac100 (P content at requirement, $3.8 \mathrm{~g} / \mathrm{kg}$ DM) } \\
\hline $\begin{array}{l}\text { *Reproduction: retained placenta and acu } \\
\text { pyometra, cystic ovaries) were subclinical }\end{array}$ & $\begin{array}{l}\text { itis were determ } \\
\text { ed at the regula }\end{array}$ & $\begin{array}{l}\text { the clinical phase } \\
\text { ination of fresh } \mathrm{cc}\end{array}$ & $\begin{array}{l}\text { diagnoses (chr } \\
\text { o weeks after }\end{array}$ & ometritis, \\
\hline
\end{tabular}




\subsection{Feed digestibility and P excretion}

The apparent faecal digestibility of NDF, OM and P were determined as well as the apparent P uptake (daily $\mathrm{P}$ intake minus faecal $\mathrm{P}$ excretion) and the apparent $\mathrm{P}$ uptake relative to the calculated net $\mathrm{P}$ requirements. Averages are shown for the different diets in Table 3.10 (prepartum diets) and Table 3.11 (postpartum diets).

Table 3.10 Apparent faecal digestibility of the two dry cow diets, $P$ excretion and apparent retention prepartum.

\begin{tabular}{|c|c|c|c|c|c|c|}
\hline & \multicolumn{2}{|c|}{ week } & \multirow[t]{2}{*}{ SED } & \multicolumn{3}{|c|}{ P value } \\
\hline & -4 & -2 & & Dry & Week & Dry $\times w$ \\
\hline \multicolumn{7}{|c|}{ NDF digestibility (\%) } \\
\hline Dry185 & 55 & 50 & \multirow{2}{*}{3.3} & \multirow{2}{*}{0.499} & \multirow{2}{*}{0.066} & \multirow{2}{*}{0.487} \\
\hline Dry100 & 52 & 50 & & & & \\
\hline \multicolumn{7}{|c|}{ OM digestibility (\%) } \\
\hline Dry185 & 59 & 56 & \multirow{2}{*}{2.8} & \multirow{2}{*}{0.389} & \multirow{2}{*}{0.277} & \multirow{2}{*}{0.429} \\
\hline Dry100 & 55 & 55 & & & & \\
\hline \multicolumn{7}{|c|}{ P digestibility (\%) } \\
\hline Dry 185 & 13 & 12 & \multirow{2}{*}{6.5} & \multirow{2}{*}{0.719} & \multirow{2}{*}{0.115} & \multirow{2}{*}{0.116} \\
\hline Dry100 & 4 & 16 & & & & \\
\hline \multicolumn{7}{|c|}{ P excretion ( $g / d)$} \\
\hline Dry185 & 47 & 42 & \multirow{2}{*}{2.8} & \multirow{2}{*}{$<0.001$} & \multirow{2}{*}{$<0.001$} & \multirow{2}{*}{0.875} \\
\hline Dry100 & 30 & 24 & & & & \\
\hline \multicolumn{7}{|c|}{ Gross retention: $P$ intake - P excretion $(g / d)$} \\
\hline Dry185 & 7 & 7 & \multirow{2}{*}{2.6} & \multirow{2}{*}{0.161} & \multirow{2}{*}{0.308} & \multirow{2}{*}{0.286} \\
\hline Dry100 & 2 & 4 & & & & \\
\hline \multicolumn{7}{|c|}{ Net retention: gross retention - calculated net $P$ requirement for gestation $(\mathrm{g} / \mathrm{d})$} \\
\hline Dry185 & 2 & 1 & \multirow{2}{*}{2.6} & \multirow{2}{*}{0.161} & \multirow{2}{*}{0.482} & \multirow{2}{*}{0.286} \\
\hline Dry100 & -3 & -1 & & & & \\
\hline
\end{tabular}

Dry185: dry cow ration with high P content (3.6 g/kg DM)

Dry100: dry cow ration with $P$ content at requirement $(2.2 \mathrm{~g} / \mathrm{kg} \mathrm{DM})$

Dry: effect of $\mathrm{P}$ content of dry cow ration

During the dry period, there was no effect of dietary $\mathrm{P}$ content on the apparent faecal digestibility of NDF or OM, suggesting that a reduced P content of $2.2 \mathrm{vs.} 3.6 \mathrm{~g} \mathrm{P} / \mathrm{kg} \mathrm{DM}$ did not negatively affect fermentation or digestion processes. For both dietary treatment groups, apparent $P$ digestibility was relatively low (on average $11 \%$ ); there was no effect of dietary $\mathrm{P}$ content on $\mathrm{P}$ digestibility. In a long term study with reduced $\mathrm{P}$ intake in the dry period and following lactation, even a negative $\mathrm{P}$ digestibility were found in the last four weeks before calving (Elizondo Salazar et al., 2012). The daily excretion of $\mathrm{P}$ with faeces was, as expected, higher on a high P diet ( $3.6 \mathrm{~g} \mathrm{P} / \mathrm{kg} \mathrm{DM}$ ) compared to the low $\mathrm{P}$ diet $(2.2 \mathrm{~g} / \mathrm{kg} \mathrm{DM})$ and decreased towards calving parallel to the decrease in dry matter intake.

Daily $P$ intake in the same weeks was on average $51 \mathrm{~g} / \mathrm{d}$ for the Dry185 diet containing $3.6 \mathrm{~g} \mathrm{P} / \mathrm{kg} \mathrm{DM}$ and $30 \mathrm{~g} / \mathrm{d}$ for the Dry100 diet containing $2.2 \mathrm{~g} \mathrm{P} / \mathrm{kg}$ DM. The difference between daily $\mathrm{P}$ intake and $\mathrm{P}$ excretion was on average $5 \mathrm{~g} P$ per day and comparable between diets. When the calculated net $\mathrm{P}$ requirement for gestation (COMV, 2005) was subtracted from the gross retention, the calculated net retention was on average $0 \mathrm{~g} / \mathrm{kg}$ DM for both groups. This suggests the high P diet with $3.6 \mathrm{~g} \mathrm{P} / \mathrm{kg} \mathrm{DM}$ (Dry185) did not result in an additional accumulation of $\mathrm{P}$ in body reserves in the cows selected for our trial, which may have already been in a positive $\mathrm{P}$ balance at the start of the experiment. 
Table 3.11 Apparent faecal digestibility postpartum.

\begin{tabular}{|c|c|c|c|c|c|c|c|c|}
\hline & \multicolumn{4}{|c|}{ week } & \multirow[t]{2}{*}{ SED } & \multicolumn{3}{|c|}{ P value } \\
\hline & 2 & 4 & 6 & 8 & & Lac & Week & Lac $\times W$ \\
\hline \multicolumn{9}{|c|}{ NDF digestibility } \\
\hline Lac70 & 58 & 58 & 51 & 52 & 2.7 & 0.901 & 0.014 & 0.236 \\
\hline Lac100 & 55 & 57 & 55 & 54 & & & & \\
\hline \multicolumn{9}{|c|}{ OM digestibility (\%) } \\
\hline \multicolumn{9}{|c|}{ P digestibility (\%) } \\
\hline Lac70 & 50 & 49 & 40 & 45 & 3.4 & 0.110 & $<0.001$ & 0.398 \\
\hline Lac100 & 46 & 41 & 40 & 40 & & & & \\
\hline Lac70 & 25 & 33 & 38 & 38 & 2.9 & $<0.001$ & $<0.001$ & 0.371 \\
\hline Lac100 & 39 & 43 & 51 & 55 & & & & \\
\hline \multicolumn{9}{|c|}{ Gross retention: $P$ intake - P excretion $(g / d)$} \\
\hline Lac70 & 26 & 30 & 26 & 30 & 2.1 & 0.070 & 0.094 & 0.356 \\
\hline Lac100 & 31 & 31 & 33 & 35 & & & & \\
\hline \multicolumn{9}{|c|}{ Net retention: gross retention - milk $P$ excretion $(g / d)$} \\
\hline Lac70 & -16 & -13 & -16 & -12 & 4.1 & 0.008 & 0.079 & 0.355 \\
\hline Lac100 & -10 & -10 & -8 & -6 & & & & \\
\hline
\end{tabular}

Lac70: lactation ration with low P content $(2.9 \mathrm{~g} / \mathrm{kg} \mathrm{DM})$

Lac100: lactation ration with P content at requirement $(3.8 \mathrm{~g} / \mathrm{kg} \mathrm{DM})$

Lac: effect of $\mathrm{P}$ content of lactation ration

The effect of dry cow diet Dry nor its interactions with the other factors (Dry $x$ Week, Dry $x$ Lac, Dry $\times$ Lac $\times$ Week) are significant $(P>0.10)$

After calving, the apparent digestibility of NDF and P decreased significantly over time (Table 3.11). This is likely related to the increasing dry matter intake in the same period, from $17 \mathrm{~kg}$ DM in week 2 up to $23 \mathrm{~kg}$ DM in week 8 (Table 3.3). There was no effect of diet on digestibility, suggesting the reduction in $\mathrm{P}$ content from 3.8 to $2.9 \mathrm{~g} \mathrm{P} / \mathrm{kg}$ DM did not negatively affect fermentation or digestion processes. This is in agreement with the study of Elizondo Salazar (2012), showing no differences in diet digestibility at $4.3,3.6$ or $2.9 \mathrm{~g} \mathrm{P} / \mathrm{kg} \mathrm{DM}$.

The daily excretion of $\mathrm{P}$ with faeces was in the first 8 weeks of lactation higher on the Lac100 diet compared to the Lac70 diet (47 vs. 34 gram per day) and increased with time, parallel to the increase in dry matter intake. The difference between daily $\mathrm{P}$ intake and $\mathrm{P}$ excretion was on average $30 \mathrm{~g} \mathrm{P}$ per day; cows on the Lac70 diet with $2.9 \mathrm{~g} \mathrm{P} / \mathrm{kg}$ DM tended to have a lower gross P retention ( $28 \mathrm{vs} .32 \mathrm{~g}$ $\mathrm{P}$ per day, $\mathrm{P}=0.070)$.

When the calculated net $\mathrm{P}$ excretion with milk was subtracted from the gross retention, the calculated net retention was negative suggesting cows on both diets must have mobilized $P$ body reserves (Table 3.11). Net retention was on average lower for the Lac70 diet compared to Lac100 ( $-14 \mathrm{vs}$. $-9 \mathrm{~g} P$ per day) and tended to increase in both groups towards the $8^{\text {th }}$ lactation week $(P=0.079)$.

The $\mathrm{P}$ excretion with milk was also expressed as a relative value of total $\mathrm{P}$ intake, as an indicator for $\mathrm{P}$ efficiency. As expected, the $P$ efficiency was clearly higher for cows fed the Lac70 diet $(P<0.001$, Figure 3.8). The $P$ content of the dry cow diet did not affect $P$ efficiency $(P>0.10)$. 


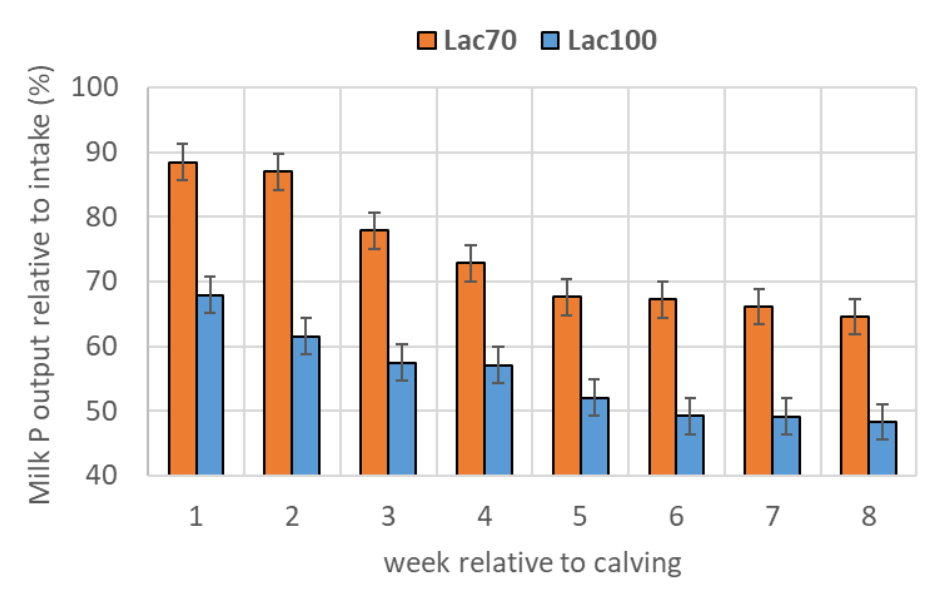

Figure 3.8 Milk $P$ output relative to dietary $P$ intake ( $P$ efficiency, $\%)$ averaged per lactation ration group in week 1 to 8 after calving (error bars representing SED). 


\section{Conclusions}

In the dry period (final 6 weeks before calving) a dietary $P$ content above calculated requirements (3.6 $\mathrm{g} \mathrm{P} / \mathrm{kg} \mathrm{DM}$ ) does not affect feed intake, milk yield or milk composition of dairy cows in the first 8 weeks after calving compared to a dry cow diet at $P$ requirements $(2.2 \mathrm{~g} \mathrm{P} / \mathrm{kg} \mathrm{DM})$. Extra $\mathrm{P}$ intake does not result in any additional accumulation of $\mathrm{P}$ in body reserves, but it may negatively affect calcium homeostasis and increase the risk for (subclinical) hypocalcemia postpartum.

A reduction of the dietary $\mathrm{P}$ content in lactation diets below the calculated requirements $(2.9 \mathrm{~g} \mathrm{P} / \mathrm{kg}$ DM) reduced average plasma $\mathrm{P}$ concentration and increased plasma Ca concentration in the first 8 weeks postpartum compared to a diet at requirements $(3.8 \mathrm{~g} \mathrm{P} / \mathrm{kg} \mathrm{DM})$. There were no effects of the reduced $\mathrm{P}$ intake on feed intake, milk yield, milk composition or animal health.

A reduction of the $\mathrm{P}$ content of dry cow or lactation diets does not seem to negatively affect rumen fermentation or digestibility of the diets, as the apparent NDF and OM digestibility remained unaffected.

The $\mathrm{P}$ requirements for dry cows may be reconsidered, as the apparent $\mathrm{P}$ digestibility still seem to be rather low when feeding at the current requirements. The calculated net retention of $\mathrm{P}$ (corrected for the net $P$ requirements for gestation) was around 0 , suggesting no body mobilisation or accumulation during the dry period. A further reduction of $\mathrm{P}$ in dry cow diets may be possible to reduce environmental $P$ excretion without negatively affecting health or cow performance. Moreover, overfeeding $\mathrm{P}$ during the dry period may negatively affect calcium homeostasis increasing the risk for hypocalcemia during early lactation.

In the first 8 weeks postpartum, calculated body mobilisation of $\mathrm{P}$ was on average 14 gram per day for the low P diet ( $2.9 \mathrm{~g} \mathrm{P} / \mathrm{kg} \mathrm{DM}$ ) and 9 gram per day for the diet aimed at requirements ( $3.8 \mathrm{~g} \mathrm{P} / \mathrm{kg} \mathrm{DM}$ ) to support lactation. The efficiency of $\mathrm{P}$ utilisation for milk $\mathrm{P}$ production was $19 \%$ units higher for the low P diet (74\% vs. $55 \%)$.

Even though $\mathrm{P}$ balance was negative and body mobilisation was on average 14 gram $\mathrm{P}$ per day in cows fed the low P lactation diet ( $2.9 \mathrm{~g} \mathrm{P} / \mathrm{kg} \mathrm{DM})$, the excretion with faeces was still around $34 \mathrm{gram} \mathrm{P} \mathrm{per}$ day. This rate of $\mathrm{P}$ mobilisation hence seems to be possible without negatively affecting health or performance, but it requires accumulation of $\mathrm{P}$ later in lactation to replenish the body $\mathrm{P}$ reserves. The preferred maximal duration of a period with significant $\mathrm{P}$ mobilisation requires further research. 


\section{References}

Cohrs, I., M. R. Wilkens and W. Grünberg. 2018. Short communication: effect of dietary phosphorus deprivation in late gestation and early lactation on the calcium homeostasis of periparturient dairy cows. Journal of Dairy Science 101:9591-9598.

COMV. 2005. Handleiding mineralenvoorziening rundvee, schapen en geiten. CVB, Lelystad, pp. 5159. [in Dutch]

Goff, J.P., K. Kimura and R.L. Horst. 2002. Effect of Mastectomy on Milk Fever, Energy, and Vitamins $A, E$, and $\beta$-Carotene Status at Parturition. Journal of Dairy Science 85:1427-1436.

Goselink, R.M.A., G. Klop, J. Dijkstra and A. Bannink. 2014. Phosphorus metabolism in dairy cattle; a literature study on recent developments and missing links. Wageningen, Wageningen UR (University \& Research centre) Livestock Research, Livestock Research Report 910.

Grünberg, W. 2014. Treatment of Phosphorus Balance Disorders. Veterinary Clinics of North America Food Animal Practice 30:383-408.

Puggaard, L., P. Lund, A. Liesegang and J. Sehested. 2014. Long term effect of reduced dietary phosphorus on feed intake and milk yield in dry and lactating dairy cows. Livestock Science 159:18-28.

Elizondo Salazar, J.A., J.D. Ferguson, D.B. Beegle, D.W. Remsburg and Z. Wu. 2013. Body phosphorus mobilization and deposition during lactation in dairy cows. Journal of Animal Physiology and Animal Nutrition 97:502-514.

Valk, H. and L.B.J. Šebek. 1999. Influence of long-term feeding of limited amounts of phosphorus on dry matter intake, milk production, and body weight of dairy cows. Journal of Dairy Science 82 : 2157-2163. 


\section{Appendix 1 Chemical analysis and feeding value of dietary ingredients}

Table A1.1 Grass silages per batch, including relative contribution (intake per batch relative to total grass silage intake) during the trial.

\begin{tabular}{|c|c|c|c|c|c|c|}
\hline Batch & GK_2016_12 & GK_2016_13 & GK_2016_4 & GK_2016_16 & GK_2016_14 & GK_2016_1B \\
\hline \multicolumn{7}{|l|}{ Feed management } \\
\hline Period fed (2017) & Jan & Feb-Mar & Apr & May-Jun & Jul-Aug & Sep \\
\hline \multicolumn{7}{|c|}{ Parameter (g/kg DM, unless stated differently) } \\
\hline \multicolumn{7}{|l|}{ Chemical analysis } \\
\hline $\mathbf{P}$ & 3.0 & 3.5 & 3.6 & 4.1 & 4.7 & 5.4 \\
\hline OM & 900 & 899 & 897 & 876 & 873 & 870 \\
\hline $\mathrm{CP}$ & 84 & 99 & 97 & 119 & 130 & 152 \\
\hline Crude fibre & 337 & 325 & 345 & 292 & 278 & 225 \\
\hline Starch & - & - & - & - & - & - \\
\hline Sugars & 36 & 20 & 16 & 60 & 26 & 49 \\
\hline $\mathrm{Na}$ & 1.5 & 1.5 & 1.8 & 1.8 & 3.0 & 3.4 \\
\hline $\mathrm{K}$ & 28.2 & 30.6 & 30.2 & 32.4 & 34.4 & 33.2 \\
\hline $\mathrm{Mg}$ & 1.4 & 1.5 & 1.5 & 1.7 & 2.1 & 2.4 \\
\hline $\mathrm{Ca}$ & 4.4 & 4.7 & 4.8 & 6.1 & 7.0 & 6.1 \\
\hline $\mathrm{S}$ & 2.1 & 2.5 & 2.9 & 3.3 & 3.8 & 5.4 \\
\hline $\mathrm{Cl}$ & 10.8 & 11.3 & 10.7 & 10.0 & 12.2 & 8.5 \\
\hline $\mathrm{DCAD}(\mathrm{mEq} / \mathrm{kg} \mathrm{DM})$ & 352 & 374 & 369 & 421 & 427 & 421 \\
\hline \multicolumn{7}{|l|}{ Feeding value } \\
\hline OEB\# 2007 & 3 & 21 & 29 & 17 & 39 & 50 \\
\hline
\end{tabular}

*DVE (Darm Verteerbaar Eiwit): intestinal digestible protein according to CVB.

\#OEB (Onbestendig Eiwit Balans): rumen digestible protein balance according to CVB. 
Table A1.2 Maize silages per batch, including relative contribution (intake per batch relative to total maize silage intake) during the trial; as well as the average composition of soy bean meal and wheat straw during the total trial.

\begin{tabular}{|c|c|c|c|c|c|c|}
\hline Batch & MK_2016_15 & MK_2016_3 & MK_SLURF & MK_BAAL & $\begin{array}{c}\text { Soy bean } \\
\text { meal }\end{array}$ & Wheat straw \\
\hline \multicolumn{7}{|l|}{ Feed management } \\
\hline $\begin{array}{l}\text { Batch contribution } \\
\text { relative to total } \\
\text { intake }\end{array}$ & $20 \%$ & $25 \%$ & $51 \%$ & $3 \%$ & & \\
\hline \multicolumn{7}{|c|}{ Parameter (g/kg DM, unless stated differently) } \\
\hline $\mathrm{DM}(\mathrm{g} / \mathrm{kg})$ & 366 & 336 & 348 & 342 & 867 & 883 \\
\hline \multicolumn{7}{|l|}{ Chemical analysis } \\
\hline $\mathbf{P}$ & 2.5 & 2.5 & 2.1 & 2.1 & 6.9 & 0.7 \\
\hline OM & 952 & 948 & 965 & 964 & 931 & 932 \\
\hline $\mathrm{CP}$ & 52 & 48 & 63 & 61 & 494 & 22 \\
\hline ADL & 29 & 25 & 31 & 31 & 11 & 48 \\
\hline Crude fat & 34 & 34 & 34 & 34 & 19 & 11 \\
\hline Starch & 358 & 341 & 334 & 339 & 35 & - \\
\hline Sugars & - & - & - & - & 112 & - \\
\hline $\mathrm{Na}$ & 0.1 & 0.1 & 0.1 & 0.1 & 0.2 & 0.5 \\
\hline $\mathrm{K}$ & 13.5 & 13.4 & 12.4 & 12.4 & 24.4 & 14.4 \\
\hline $\mathrm{Mg}$ & 1.1 & 1.3 & 1.1 & 1.1 & 3.8 & 0.8 \\
\hline $\mathrm{Ca}$ & 1.8 & 2 & 1.9 & 1.9 & 3.6 & 3.2 \\
\hline $\mathrm{S}$ & 1 & 1 & 1.0 & 1 & 4.3 & 1.1 \\
\hline $\mathrm{Cl}$ & 2.4 & 2.9 & 2.1 & 2.1 & 0.5 & 0.0 \\
\hline DCAD (mEq/kg DM) & 220 & 203 & 200 & 200 & 350 & 321 \\
\hline OEB ${ }^{\#} 1991$ & -44 & -46 & -35 & -36 & 177 & -57 \\
\hline DVE* 2007 & 47 & 45 & 48 & 48 & 256 & -7 \\
\hline OEB\# 2007 & -43 & -45 & -35 & -37 & 193 & -25 \\
\hline
\end{tabular}

*DVE (Darm Verteerbaar Eiwit): intestinal digestible protein according to CVB.

\#OEB (Onbestendig Eiwit Balans): rumen digestible protein balance according to CVB. 
Table A1.3 Ingredients and composition of premixes (added to the mixed roughage diets) and compound concentrates (fed individually in transponder-controlled automatic feeders).

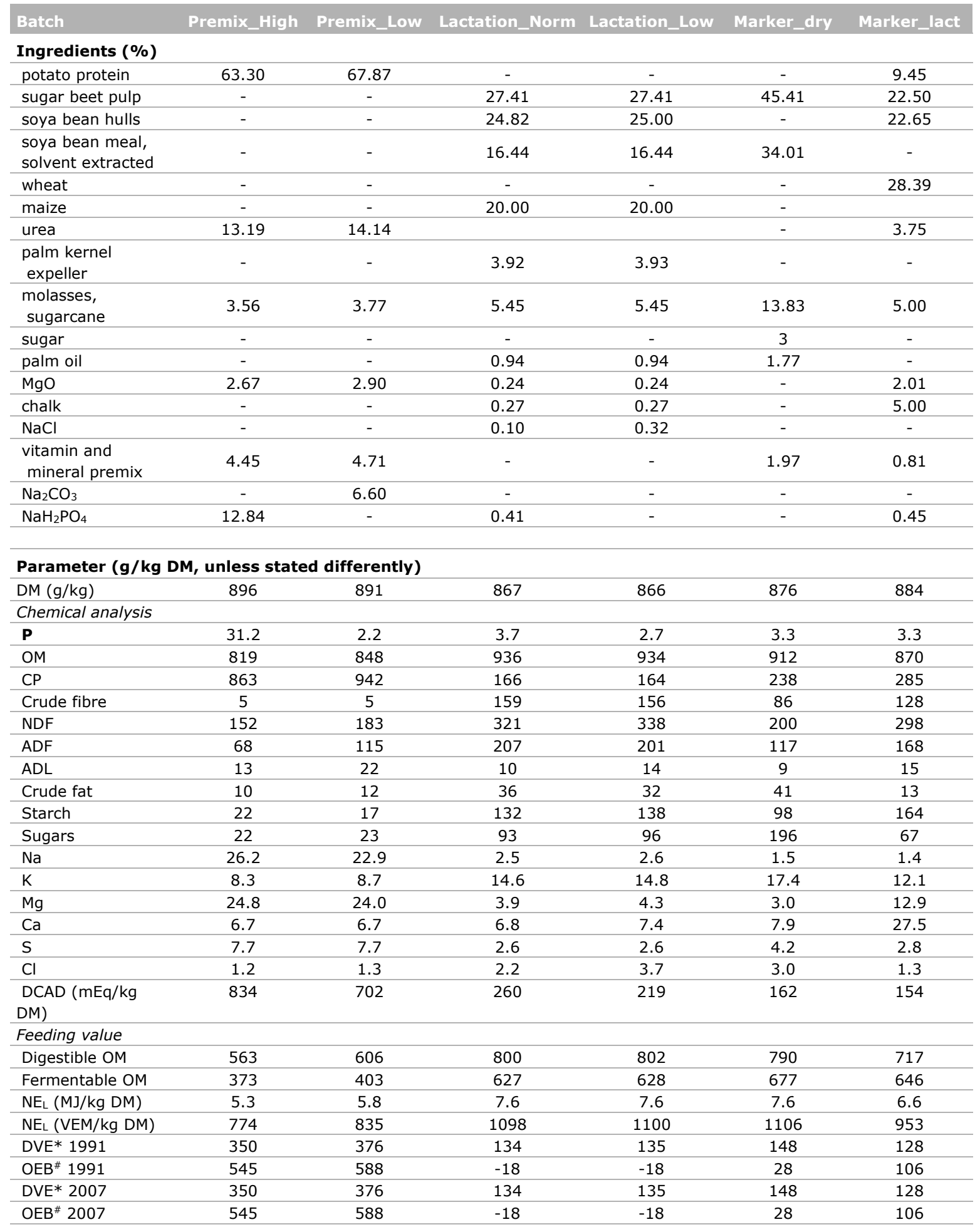

*DVE (Darm Verteerbaar Eiwit): intestinal digestible protein according to CVB.

\#OEB (Onbestendig Eiwit Balans): rumen digestible protein balance according to CVB. 


\section{Appendix 2 Additional figures}

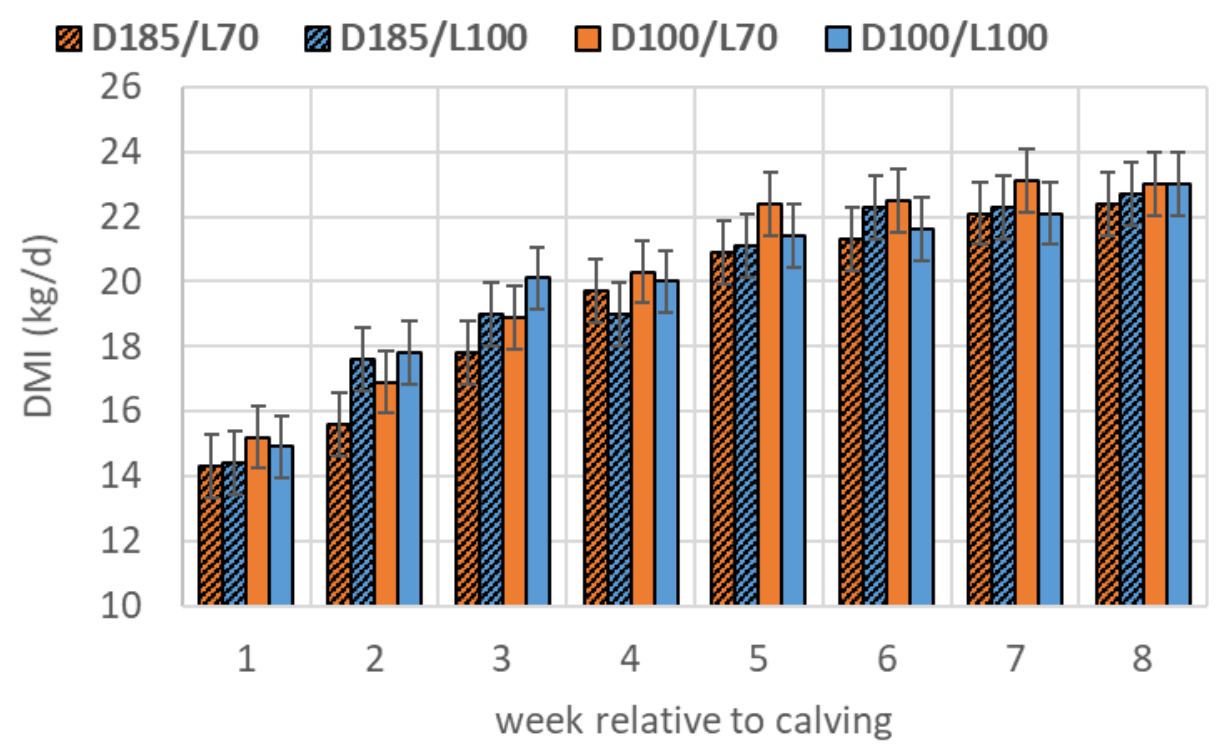

Figure A2.1 Dry matter intake in early lactation (week 1 to 8), averaged per treatment group ( $k g D M / c o w$ per day, error bars representing SED).

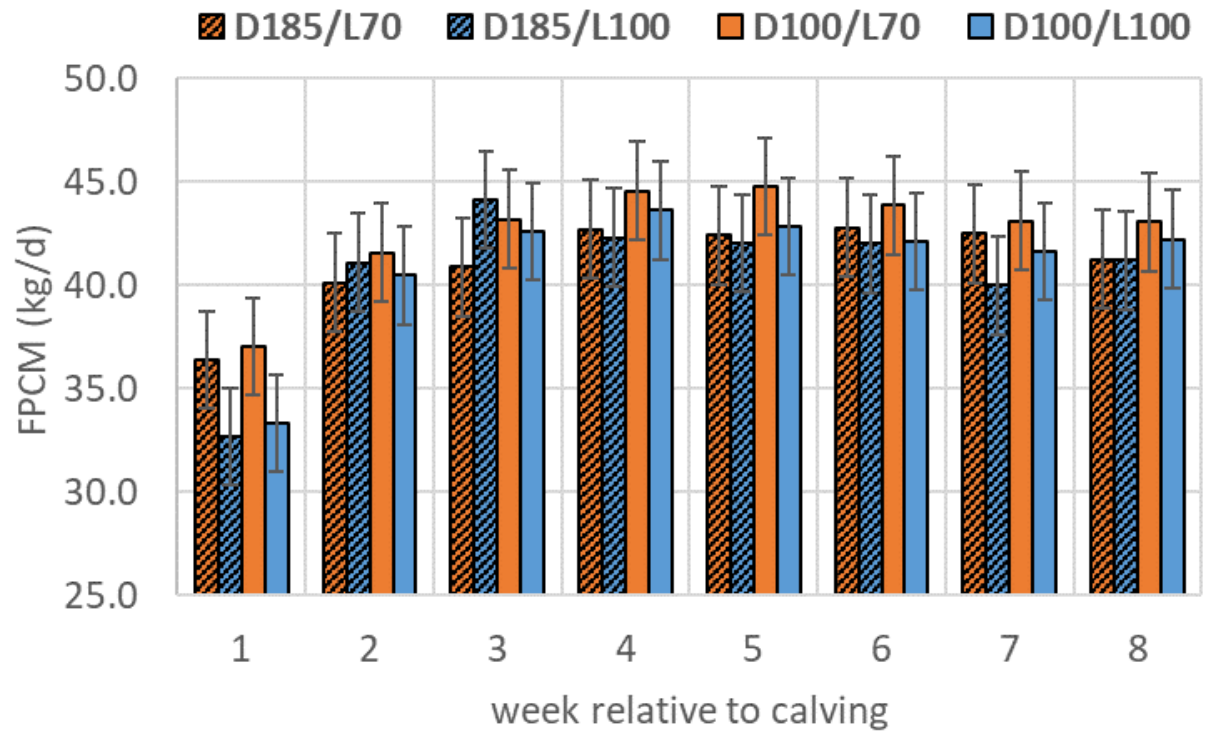

Figure A2.2 Fat and Protein Corrected Milk (FPCM) yield in early lactation (week 1 to 8), averaged per treatment group ( $\mathrm{kg} / \mathrm{cow}$ per day, error bars representing SED). 


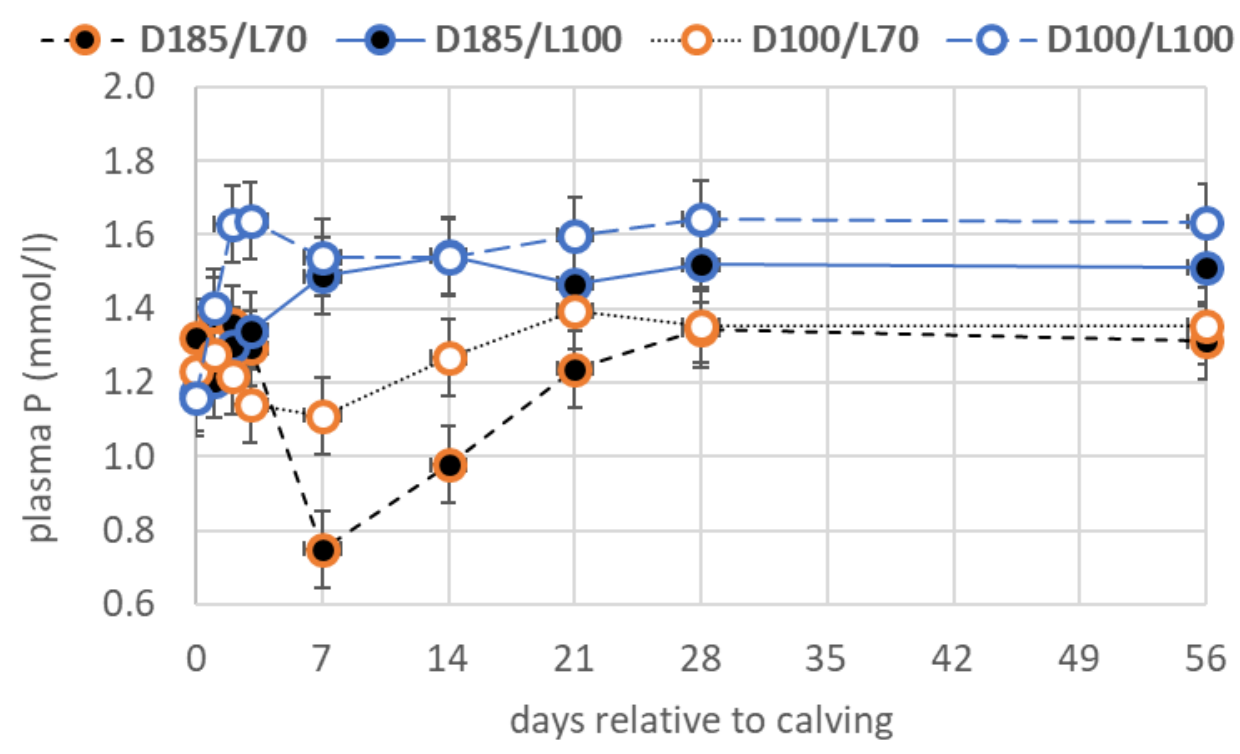

Figure A2.3 Plasma $P$ concentration in early lactation (week 1 to 8), averaged per treatment group ( $\mathrm{kg} / \mathrm{cow}$ per day, error bars representing SED).

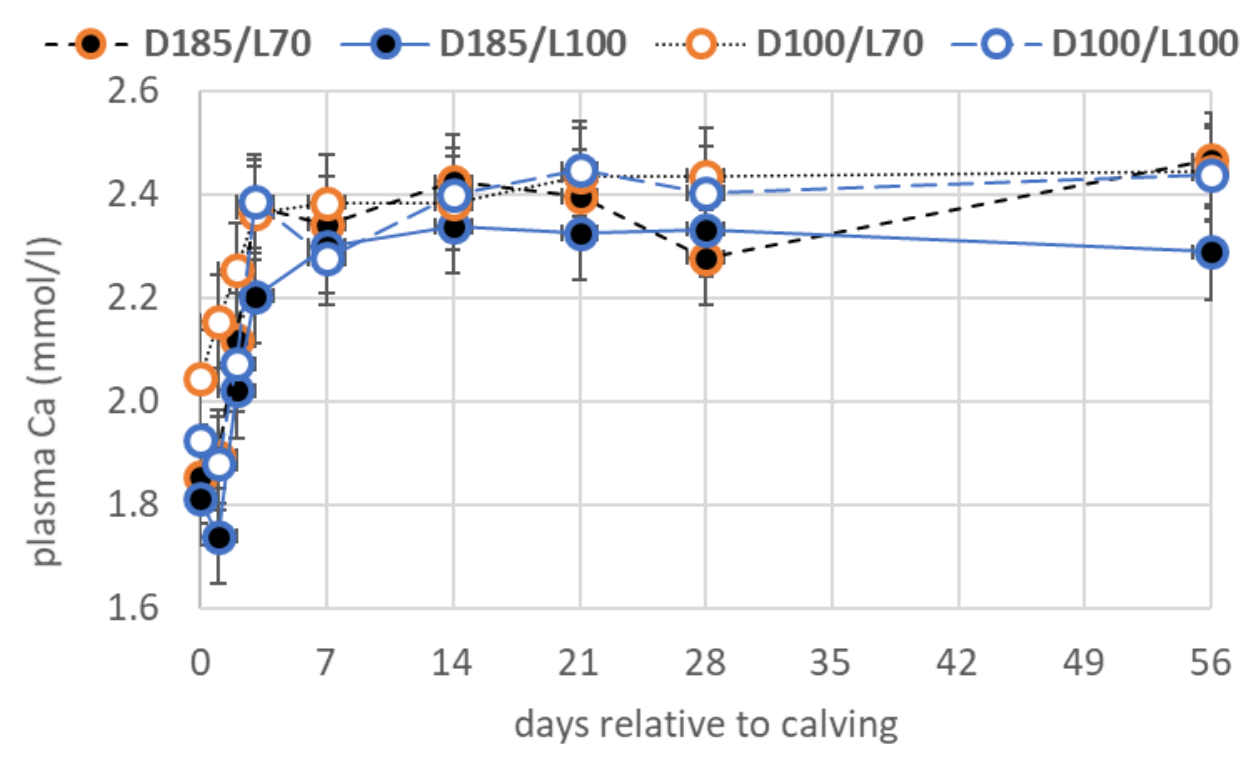

Figure A2.4 Plasma Ca concentration in early lactation (week 1 to 8), averaged per treatment group ( $\mathrm{kg} / \mathrm{cow}$ per day, error bars representing SED). 


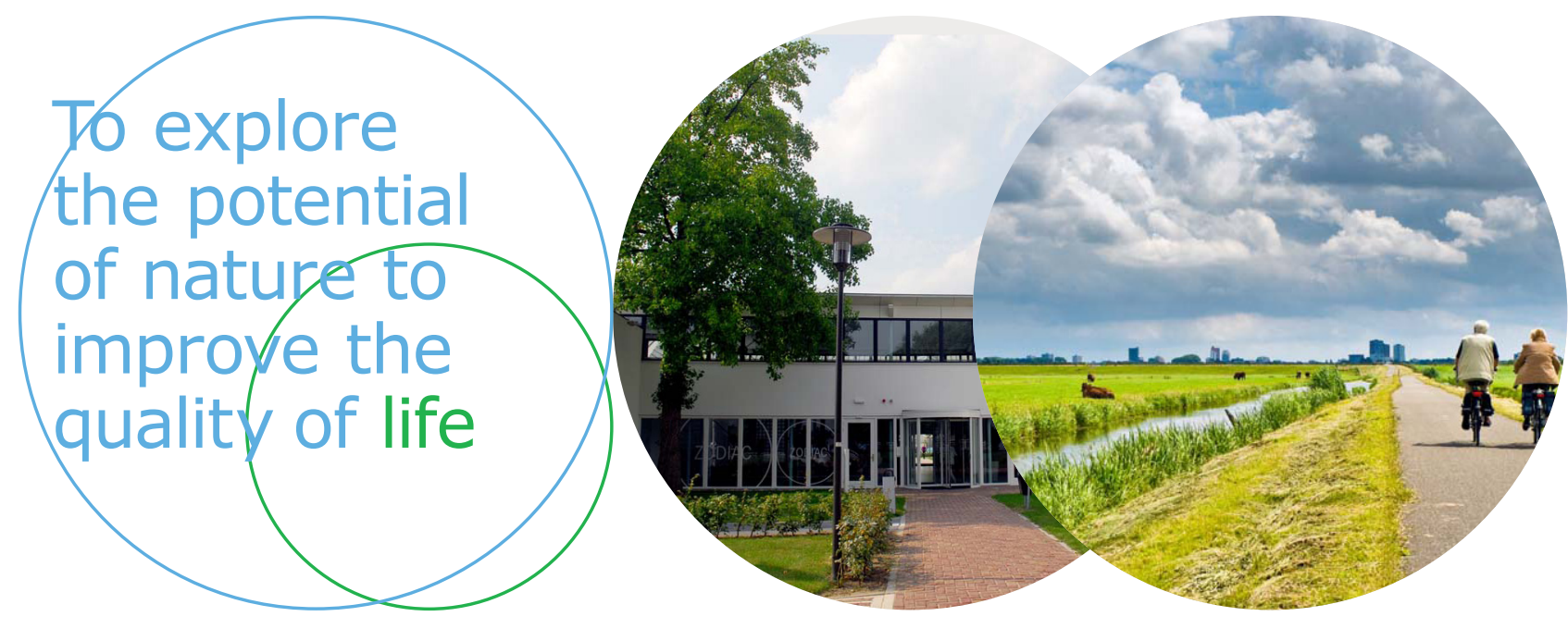

Wageningen Livestock Research P.O. Box 338

6700 AH Wageningen

The Netherlands

$\mathrm{T}+31(0) 317483953$

E info.livestockresearch@wur.nl

www.wur.nl/livestock-research

Wageningen Livestock Research creates science based solutions for a sustainable and profitable livestock sector. Together with our clients, we integrate scientific knowledge and practical experience to develop livestock concepts for future generations.

Wageningen Livestock Research is part of Wageningen University \& Research. Together we work on the mission: 'To explore the potential of nature to improve the quality of life'. A staff of 6,500 and 10,000 students from over 100 countries are working worldwide in the domain of healthy food and living environment for governments and the business community-at-large. The strength of Wageningen University \& Research lies in its ability to join the forces of specialised research institutes and the university. It also lies in the combined efforts of the various fields of natural and social sciences. This union of expertise leads to scientific breakthroughs that can quickly be put into practice and be incorporated into education. This is the Wageningen Approach. 